\title{
NITRIC OXIDE REMOVAL BY COMBINED PERSULFATE AND FERROUS-EDTA REACTION SYSTEMS
}

\author{
Yusuf G. Adewuyi*and Md A. Khan
}

Chemical, Biological and Bioengineering Department

North Carolina Agricultural and Technical State University

Greensboro, NC 27411 USA

To whom correspondence should be addressed.

Phone: (336) 334-7564 or (336) 285-3651.

Fax: (336) 334-7417

E-mail: adewuyi@ncat.edu 


\begin{abstract}
Nitric oxide (NO) removal from simulated flue gas is investigated using combined aqueous persulfate $\left(\mathrm{Na}_{2} \mathrm{~S}_{2} \mathrm{O}_{8}\right)$ and ferrous ethylenediaminetetraacetate $\left(\mathrm{Fe}^{2+}\right.$-EDTA) systems. The results at $23-70{ }^{\circ} \mathrm{C}$ showed significant improvement in NO removal using the optimally obtained molar ratio of 1:1 for the $\mathrm{Fe}^{2+}$ and EDTA compared with temperature-only and combined temperature$\mathrm{Fe}^{2+}$ activated persulfate systems with $0.1 \mathrm{M} \mathrm{Na}_{2} \mathrm{~S}_{2} \mathrm{O}_{8}$ and $0.01 \mathrm{M} \mathrm{Fe}^{2+}$ in the absence of EDTA. Almost $100 \%$ NO conversion can be achieved at $70{ }^{\circ} \mathrm{C}$ (flue gas treatment inlet temperature generally at $50-70{ }^{\circ} \mathrm{C}$ ) compared to temperature and $\mathrm{Fe}^{2+}$-activated persulfate systems which require $\geq 90{ }^{\circ} \mathrm{C}$ for such high removal efficiency. The percentage increases in NO removal were dependent on temperature, $25-30 \%$ and $5-10 \%$ at the lower $\left(<40{ }^{\circ} \mathrm{C}\right)$ and higher $\left(>40{ }^{\circ} \mathrm{C}\right)$ temperatures, respectively. A very high concentration of $\mathrm{Fe}^{\mathrm{II}}$-EDTA appears to negatively impact NO removal. However, this process operates at an optimal NO removal $\mathrm{pH}$ of near neutral $(\sim 6.5)$ with efficiency decreasing at very low or high $\mathrm{pH}$. This should reduce the use of auxiliary chemical for $\mathrm{pH}$ adjustment and help mitigate the important technological hurdle of undesired ferric product formation associated with $\mathrm{Fe}^{2+}$-only activated persulfate and other Fenton-like systems at $\mathrm{pH}(>3.5)$. The material balance on iron species $\left(\mathrm{Fe}^{2+}, \mathrm{Fe}^{3+}\right.$ and $\mathrm{Fe}^{2+}$-EDTA) was determined to better understand the chemistry of persulfate with $\mathrm{Fe}^{2+}$-EDTA for NO removal. The results demonstrate the feasibility of near complete NO removal at relatively lower temperatures (with the advantage of reduced energy usage), and sustained longtime high NO absorption capability.
\end{abstract}

Keywords: Nitric Oxide; Absorption; Oxidation; Persulfate, Ferrous-EDTA; Activation. 


\section{INTRODUCTION}

Nitrogen oxides $\left(\mathrm{NO}_{\mathrm{x}}-\right.$ mainly $\mathrm{NO}_{2}$ and $\left.\mathrm{NO}\right)$ and sulfur oxides $\left(\mathrm{SO}_{\mathrm{x}}-\right.$ mainly $\left.\mathrm{SO}_{2}\right)$ released from the burning of fossil fuel, especially from the coal-fired power plants, cause considerable environmental and health problems.[1,2] Of these oxides, $\mathrm{NO}_{2}$ and $\mathrm{SO}_{2}$ are very soluble in water and can be separated easily from the exhaust stream by simple scrubbing, but nitric oxide (NO) is sparingly soluble and cannot be separated easily. It is well known that the commonly practiced methods of removing NO such as selective catalytic and non-catalytic processes have high capital costs and undesirable problems with high temperatures and handling of harmful chemicals. Therefore, alternative cost-effective and environmentally friendlier processes such as using wet scrubbing agents, capable of significantly increasing the solubility of NO in water, are of ardent interest.[3-7] As a result, the uses of aqueous solutions of $\mathrm{H}_{2} \mathrm{O}_{2}, \mathrm{NaClO}_{2}, \mathrm{KMnO}_{4}$, iron and cobalt chelated compounds, and sonochemical oxidation processes for NO removal, are the subjects of a number of recent studies.[8-15] In 2010, Khan and Adewuyi reported, for the first time, the use of aqueous sodium persulfate $\left(\mathrm{Na}_{2} \mathrm{~S}_{2} \mathrm{O}_{8}\right)$ activated by temperature for NO removal, and commented on its safety, stability and environmental benign nature.[6] The persulfate or peroxydisulfate anion $\left(\mathrm{S}_{2} \mathrm{O}_{8}{ }^{2-}\right)$ is a strong and non-selective oxidant $\left(\mathrm{E}^{\mathrm{o}}=2.01 \mathrm{~V}\right)$ comparable to $\mathrm{O}_{3}$ and $\mathrm{H}_{2} \mathrm{O}_{2}$, both of which are widely used in water and wastewater treatment.[16-19]

$S_{2} O_{8}^{2-}+2 e^{-} \rightarrow 2 \mathrm{SO}_{4}^{2-}, \quad \mathrm{E}^{\mathrm{o}}=2.01 \mathrm{~V}$

However, it is kinetically slow at ordinary conditions and often activated by heat, light, ultrasound or transition metal ions such as $\mathrm{Fe}$ (II) (or its chelate complexes) to generate intermediate sulfate free radical $\left(\mathrm{SO}_{4}^{-}\right)$as represented by the generalized eq 2 and eq 3 , respectively.

$\mathrm{S}_{2} \mathrm{O}_{8}^{2-}{ }_{(a q)}+$ heat $/$ UV $/$ Ultrasound $\quad \rightarrow 2 \mathrm{SO}_{4}^{\bullet-}$ 
$\mathrm{S}_{2} \mathrm{O}_{8}^{2-}+\mathrm{Me}_{(\mathrm{aq})}^{\mathrm{n+}} \rightarrow \mathrm{SO}_{4(\mathrm{aq})}^{\cdot-}+\mathrm{SO}_{4(\mathrm{aq})}^{2-}+\mathrm{Me}_{(a q)}^{(n+1)+}$

The decomposition reactions of the persulfate anion also vary with persulfate concentration, $\mathrm{pH}$, and oxygen, and hydrogen peroxide or peroxymonosulfate can be produced.[20]

In 2013, Adewuyi and Sakyi investigated the removal of $\mathrm{NO}$ in presence of $\mathrm{SO}_{2}$ by the aqueous persulfate systems, showing that the absorption of NO was greatly enhanced in the presence of $\mathrm{SO}_{2}\left(70-80 \% \mathrm{NO}\right.$ conversion in the temperature range of $\left.23-70{ }^{\circ} \mathrm{C}\right)$, while the $\mathrm{SO}_{2}$ itself was completely removed.[4] Adewuyi and coworkers, in their most recent studies on the removal of $\mathrm{NO}$ using $\mathrm{Na}_{2} \mathrm{~S}_{2} \mathrm{O}_{8}(0.1 \mathrm{M})$ simultaneously activated by temperature and $\mathrm{Fe}^{2+}$ ion, also found that NO removal further increased by almost $10 \%$ in presence of $\mathrm{Fe}^{2+}(0.01 \mathrm{M})$ at all temperatures $\left(23-90^{\circ} \mathrm{C}\right)$ compared to a prior study involving temperature-only activation.[5, 21] However, in these studies, initial solution $\mathrm{pH}$ was kept between 3.0 and $3.5( \pm 0.1)$ to prevent $\mathrm{Fe}^{2+}$ oxidation to $\mathrm{Fe}^{3+}$ and subsequent precipitation as $\mathrm{Fe}(\mathrm{OH})_{3}$. The thermal and $\mathrm{Fe}^{2+}$ ion activation of the persulfate anion leads to the production of the sulfate radicals $\left(\mathrm{SO}_{4}{ }^{-}\right)$, which is responsible for the production of $\mathrm{OH}^{*}$ that acts as the main oxidant for the conversion of NO in the aqueous solution.[5, 6, 21-23] The following major pathways have been proposed:

$$
\begin{aligned}
& \mathrm{S}_{2} \mathrm{O}_{8}^{2-}+\text { heat } \stackrel{\mathrm{k}_{1}=1.0 \times 10^{-7}\left(25^{\circ} \mathrm{C}\right) \text { or } 5.7 \times 10^{-7} \mathrm{~s}^{-1}\left(70^{\circ} \mathrm{C}\right)}{\longrightarrow} 2 \mathrm{SO}_{4}^{\bullet-} \\
& \mathrm{S}_{2} \mathrm{O}_{8}^{2-}+\mathrm{Fe}^{2+} \stackrel{k_{2}=1.7-2.7 \text { or } 2.0 \times 10^{1} \mathrm{M}^{-1} \mathrm{~S}^{-1}\left(70^{\circ} \mathrm{C}\right)}{\longrightarrow} \mathrm{SO}_{4}^{2-}+\mathrm{SO}_{4}^{\bullet-}+\mathrm{Fe}^{3+}
\end{aligned}
$$




$$
\begin{aligned}
& \mathrm{S}_{2} \mathrm{O}_{8}^{2-}+\mathrm{NO}_{2}^{-} \stackrel{k_{5}}{\rightarrow} \mathrm{SO}_{4}^{2-}+\mathrm{SO}_{4}^{\cdot-}+\mathrm{NO}_{2} \\
& \mathrm{NO}_{2}^{-}+\mathrm{SO}_{4}^{--} \stackrel{k_{6}=9.8 \times 10^{8} \mathrm{M}^{-1} \mathrm{~S}^{-1}}{\longrightarrow} \mathrm{SO}_{4}^{2-}+\mathrm{NO}_{2} \\
& \mathrm{NO}_{2}+\mathrm{OH}^{\bullet} \stackrel{k_{7}=4.5 \times 10^{9} \mathrm{M}^{-1} \mathrm{~S}^{-1}}{\longrightarrow} \mathrm{H}^{+}+\mathrm{NO}_{3}^{-} \\
& \mathrm{S}_{2} \mathrm{O}_{8}^{2-}+\mathrm{NO}+\mathrm{H}_{2} \mathrm{O} \stackrel{k_{2}^{\prime}=2.59 \times 10^{-4}\left(23^{\circ} \mathrm{C}\right)-1.59 \times 10^{-3}\left(90^{\circ} \mathrm{C}\right) \mathrm{M}^{-1} \mathrm{~S}^{-1}}{\longrightarrow} 2 \mathrm{HSO}_{4}^{-}+\mathrm{NO}_{2}(\text { ref 23) } \\
& \mathrm{Fe}^{2+}+\mathrm{OH}^{\cdot \stackrel{k_{8}=3.2 \times 10^{8} \mathrm{M}^{-1} \mathrm{~s}^{-1}}{\longrightarrow}} \mathrm{Fe}^{3+}+\mathrm{OH}^{-} \\
& \mathrm{SO}_{4}^{\cdot-}+\mathrm{Fe}^{2+} \stackrel{k_{9}=3.0 \times 10^{8}, 4.6 \times 10^{9} M^{-1} S^{-1}}{\longrightarrow} \mathrm{Fe}^{3+}+\mathrm{SO}_{4}^{2-} \\
& \mathrm{SO}_{4}^{\bullet-}+\mathrm{OH}^{\bullet} \stackrel{k_{10}=1 \times 10^{10} \mathrm{M}^{-1} \mathrm{~S}^{-1}}{\longrightarrow} \mathrm{HSO}_{4}^{-}+1 / 2 \mathrm{O}_{2} \\
& \mathrm{SO}_{4}^{\cdot-}+\mathrm{SO}_{4}^{\bullet-} \stackrel{k_{11}=4.0 \times 10^{8} \mathrm{M}^{-1} \mathrm{~S}^{-1}}{\longrightarrow} \mathrm{S}_{2} \mathrm{O}_{8}^{2-}
\end{aligned}
$$

A number of reports have suggested NO removal by iron chelating agent such as ferrous nitrilotriacetic acid (NTA), hydroxyethylethylenediaminetriacetic acid (HEDTA), diethylenetriaminepentacetic acid (DPTA), and cobalt ethylenediamine solutions.[24, 25] But the use of chelated ferrous ethylenediaminetetraacetic acid $\left(\mathrm{Fe}^{2+}\right.$-EDTA) with or without some other reagents $\left(\mathrm{Fe}^{2+}\right.$-citrate, $\left.\mathrm{Na}_{2} \mathrm{SO}_{3}, \mathrm{MgSO}_{3}, \mathrm{Na}_{2} \mathrm{~S}_{2} \mathrm{O}_{4}\right)$ is the most widespread and prevalent in literature, where NO is combined with $\mathrm{Fe}^{2+}$-EDTA by reversible binding and separated from the solution.[25-28] Although Fe ${ }^{2+}$-EDTA can obtain a high NO removal efficiency, it is easily oxidized (by $\mathrm{NO}, \mathrm{NO}_{2}$ and $\mathrm{O}_{2}$ in the flue gas) to $\mathrm{Fe}^{3+}$-EDTA that is not capable of binding NO. As a result, the concentration of the active $\mathrm{Fe}^{2+}$-EDTA in the scrubbing solutions decreases quickly as the absorption proceeds. Hence, the main drawbacks of this process include removal of the $\mathrm{Fe}^{2+}$-EDTA(NO) complex, fast oxidation of $\mathrm{Fe}^{2+}$-EDTA to the inert $\mathrm{Fe}^{3+}$-EDTA and high cost of EDTA. The problems can be somewhat overcome in BioDeNOx process where $\mathrm{Fe}^{2+}$ - 
EDTA(NO) is broken down by denitrifying bacteria and $\mathrm{Fe}^{3+}$-EDTA is reduced by iron reducing bacteria and resultant $\mathrm{Fe}^{2+}$-EDTA is recycled back to the reactor.[29] But the process has been impeded by the slow action of the biological process, uncertainty involving bacteria culture, detrimental effect of sulfur compounds present in flue gas and the costs of installing additional unit.[30-32] Also, many methods have been put forward to regenerate $\mathrm{Fe}^{2+}$-EDTA to sustain the $\mathrm{NO}$ removal through denitrification and/or reduction using sulfur derived ions, from $\mathrm{Na}_{2} \mathrm{SO}_{3}$, $\mathrm{MgSO}_{3}, \mathrm{Na}_{2} \mathrm{~S}_{2} \mathrm{O}_{4}$ etc.), in combinative processes.[26, 28] It has also been suggested that both $\mathrm{Fe}^{2+}$-EDTA and $\mathrm{Fe}^{3+}$-EDTA can also activate persulfate anion, like ferrous ion, thus producing a complete synergistic relationship with the persulfate.[33] Ahmad et al. [34] investigated extensively the Fe-EDTA activated persulfate systems using reactant-specific probes and electron spin resonance (ESR) and concluded that both $\mathrm{Fe}^{2+}$-EDTA and $\mathrm{Fe}^{3+}$-EDTA decompose persulfate more rapidly than only $\mathrm{Na}_{2}$-EDTA. Thus, it is widely reported in the literature that $\mathrm{Fe}^{3+}$-EDTA can also be reduced by $\mathrm{S}_{2} \mathrm{O}_{8}{ }^{2-}, \mathrm{SO}_{4}{ }^{-{ }^{-}}$, and bisulfate and bisulfide ions, and the resulting $\mathrm{Fe}^{2+}$-EDTA recycled for reuse. Liang et al.[35] reported that $\mathrm{Fe}^{3+}$-EDTA can maintain persulfate activation by promoting recycling of $\mathrm{Fe}$ much as in catalyzed $\mathrm{H}_{2} \mathrm{O}_{2}$ propagation (i.e., modified Fenton's reagent), suggesting an interaction of an intermediate organic radical with $\mathrm{Fe}^{3+}$ to recycle $\mathrm{Fe}^{2+}$ which was then complexed again with EDTA. Additionally, Li et al. [36], by measuring hydroxyl radical formation, suggests that Fenton and Fenton like reactions were never suppressed by iron-chelating agents. Also, the use of chelating agents has been shown to increase the $\mathrm{Fe}^{2+}$ solubility, maximizing its availability in groundwater remediation processes.[35]

However, to the best of our knowledge, the simultaneous and synergistic application of persulfate anion $\left(\mathrm{S}_{2} \mathrm{O}_{8}{ }^{2-}\right)$ and $\mathrm{Fe}^{2+}$-EDTA for NO removal has never been studied. In this work, the removal of nitric oxide (NO) from simulated flue gas in a bubble column reactor at 
atmospheric pressure is investigated using combined aqueous persulfate $\left(\mathrm{Na}_{2} \mathrm{~S}_{2} \mathrm{O}_{8}\right)$ and ferrous ethylenediaminetetraacetate $\left(\mathrm{Fe}^{2+}\right.$-EDTA) systems to demonstrate the significance and advantages over $\mathrm{Fe}^{2+}$-only activated systems previously reported.[5, 21] The effects of different process variables, such as the molar ratio of $\mathrm{Fe}^{2+}$ and EDTA, temperature and $\mathrm{pH}$, on the fractional conversion of NO were determined. The material balance on the iron species $\left(\mathrm{Fe}^{2+}\right.$, $\mathrm{Fe}^{3+}$ and $\mathrm{Fe}^{2+}$-EDTA) has been determined to understand the simultaneous and synergistic relationship between persulfate and $\mathrm{Fe}^{2+}$-EDTA on NO removal.

\section{EXPERIMENTAL SECTION}

2.1. Chemicals and Reagents. Sodium persulfate $\left(\mathrm{Na}_{2} \mathrm{~S}_{2} \mathrm{O}_{8}\right.$, powder, $\left.>98 \%\right)$, iron (II) sulfate heptahydrate $\left(\mathrm{FeSO}_{4} .7 \mathrm{H}_{2} \mathrm{O},>99 \%\right)$, concentrated sulfuric acid $(95-98 \%)$ and $1.0 \mathrm{~N}$ sodium hydroxide solution were obtained from Acros Organics, Morris Plains, NJ; disodium ethylenediaminetetraacetate $\left(\mathrm{Na}_{2}\right.$-EDTA, reagent grade), 1, 10-phenanthroline monohydrate (PTM), hydroxylamine hydrochloride (96\%), acetic acid (99.7\%), anhydrous sodium acetate (99\%), fuming nitric acid (90\%) and sodium hydroxide (solid) were obtained from Fisher Chemical, Fair Lawn, NJ; and 5.0 N sulfuric acid from LabChem Inc., Pittsburg, PA. Extra-dry nitrogen $\left(\mathrm{N}_{2}\right)$ and standard mixtures of $\mathrm{NO}$ in ultrapure nitrogen were obtained from Airgas National Welders, Charlotte, NC. Deionized water was obtained by using a Milli-Q Advantage A 10 purifier with Elix 5 system from Millipore Corporation, Bedford, MA. The resistivity of the water was always greater than $18.2 \mathrm{M} \Omega . \mathrm{cm}$ and total organic contents (TOC), silicates and heavy metals contents were minimized to a very low parts per billion (ppb) levels.

2.2. Experimental Procedure for NO Removal. The schematic diagram (Figure 1) for the NO absorption consisted of a thermally jacketed bubble column reactor made of pyrex glass (5.1 cm i.d. × 61-cm length; Ace Glass, Inc., Vineland, NJ), flue gas blending system consisting 
of a Dynablender mass flow controller (Matheson Tri-gas, Montgomeryville, PA) with two flow transducer calibrated to allow a maximum flow of 5 standard liters per minute (SLPM) gas, and analytical train of Fourier Transform Infrared (FTIR) spectrometer (Tensor 27; Bruker Optics, Billerica, MA), and was discussed in details elsewhere.[4-6]

The scrubber was operated in a semibatch mode with the simulated gas flowing upward continuously at a rate of 0.1 SLPM through the $1 \mathrm{~L}$ total volume of stationary scrubbing solution (corresponding to a liquid height of $\sim 0.5 \mathrm{~m}$ ). The experiments were performed in the range of $23-70{ }^{\circ} \mathrm{C}$ with each temperature setting maintained with the jacketed cooling/heating system of a refrigerated bath (Neslab RTE 7D1, Thermo Scientific, Newington, NH). Initially, the column was filled with around $750 \mathrm{ml}$ of de-ionized water and temperature was allowed to reach the desired level and stabilize. Pure, dry nitrogen gas was passed through it for at least 15 min to purge it of all dissolved oxygen and then through a bypass line until a stable reading was obtained. Freshly prepared $\mathrm{Fe}^{2+}, \mathrm{Na}_{2}$ EDTA and persulfate solutions of appropriate quantity to make $1.0 \pm 0.05 \mathrm{~L}$ total volume of solution of desired concentration were added to the water consecutively. To maintain the solution $\mathrm{pH}$ at neutral level, $\mathrm{NaOH}$ and/or $\mathrm{H}_{2} \mathrm{SO}_{4}$ solution were used, the additional volume so small compared to total volume as to significantly affect the overall liquid volume or height of the reactor. It should be noted that phosphate buffer solution were used for the studies at $\mathrm{pH} 4.0,8.0$ and 10.0, and for $\mathrm{pH} 2.0$ and $12.0, \mathrm{H}_{2} \mathrm{SO}_{4}$ and $\mathrm{NaOH}(1.0$ $\mathrm{N})$ solutions were used, respectively, until the $\mathrm{pH}$ reach the desired value. Once all the reagents dissolved completely and the solution observed to turn greenish, the simulated flue gas was switched to the inlet of the reactor and bubbling through the solution issued. The dissolution of persulfate seemed rapid and even vigorous at higher temperature aided by the gas mixing action. The outlet gas reached the FTIR almost instantaneously and data acquisition was started. 
The exit gas from the reactor passed through a membrane dryer (MD-050-48P, Perma Pure, Inc.) to remove moisture prior to analysis with the Fourier transform infrared (FTIR) spectrometer equipped with a custom gas cell made by FTIR.com. Both the FTIR and membrane dryer were purged with dry, $\mathrm{CO}_{2}$ free air from laboratory gas generator (Parker Balston, Haverhill, MA) to continuously remove the moisture. $\mathrm{NO}_{\mathrm{x}}$ concentration in the outlet gas was continuously monitored and recorded by proprietary software, Enformatic FTIR Collection Manager (EFCM) from FTIR.com, calibrated with standards of different gas species obtained from Airgas National Welders. The scrubbing solution was analyzed before and after the experiment using a Dionex ICS 3000 ion chromatographic system (Dionex Corporation, Sunnyvale, CA) for anions. The solution $\mathrm{pH}$ was monitored continuously using Accumet $\mathrm{pH}$ meter 50. Initial and final $\mathrm{pH}$ was recorded for each of the experiments. The details of the analytical procedures, including the analysis of gas-phase $\mathrm{NO}_{\mathrm{x}}$ and anions in solution and the results of material balances showing mainly $\mathrm{NO}_{3}^{-}$(and not $\mathrm{NO}_{2}^{-}$) as the main products of $\mathrm{Na}_{2} \mathrm{~S}_{2} \mathrm{O}_{8}$, oxidation, are reported in previous studies.[6, 37]

2.3. Spectrophotometric Determination of Fe Species in Solution. Iron species $\left(\mathrm{Fe}^{2+}\right.$, $\mathrm{Fe}^{3+}$ and $\mathrm{Fe}^{2+}$-EDTA) were determined spectrophotometrically using Beckman DU-7500 spectrophotometer (Beckman Coulter, Inc., Fullerton, CA). For better accuracy, the concentrations of $\mathrm{Fe}^{2+}$ and total $\mathrm{Fe}$ (i.e., $\mathrm{Fe}^{2+}+\mathrm{Fe}^{3+}$ ) were determined at peak absorbance ranges of 506-512 nm and 393-399 nm, respectively, by a modified 1, 10-phenanthroline colorimetric method, and the $\mathrm{Fe}^{3+}$ calculated from the difference.[5, 38] Also, at low wavelength, $\mathrm{Fe}^{2+}$-EDTA compound shows higher absorbance and the concentration can be determined spectrophotometrically.[39] From the UV-vis spectrum of $\mathrm{Fe}^{2+}$-EDTA, it can be seen that there 
is no clear absorbance peak and a wide range of wavelength $(270-300 \mathrm{~nm})$ is selected for absorbance measurement.

2.3.1. Determination of calibration curves. Standard $\mathrm{Fe}^{2+}$ and $\mathrm{Na}_{2}$ EDTA solutions were prepared in different concentrations and dilution ratios. Previously prepared hydroxylamine hydrochloride and 1, 10-phenanthroline solutions were added to the standard $\mathrm{Fe}^{2+}$ solutions and $\mathrm{pH}$ was adjusted to 4.5 using acetic acid-sodium acetate buffer. The standard solutions in quartz cuvettes (Spectrocell Corporation, Oreland, PA) were taken to sampling compartment of the spectrophotometer already blanked using base solution (i.e., sample solution without the $\mathrm{Fe}^{2+}$ ), and absorbance was measured multiple times and recorded for each of the samples with concentrations and dilutions ratios at seven different wavelengths ranging from 506-512 nm. The corresponding absorbance of a particular concentration was found by discarding outlier data and then averaging the retentions. The calibration curves of $\mathrm{Fe}^{2+}$ were obtained at different wavelengths by plotting absorbance against the respective concentration. The same procedure was followed to determine $\left(\mathrm{Fe}^{2+}+\mathrm{Fe}^{3+}\right)$ calibration curves except for the addition of hydroxylamine hydrochloride, as it is used to regenerate $\mathrm{Fe}^{2+}$ oxidized to $\mathrm{Fe}^{3+}$. In this case, $\mathrm{pH}$ was kept at 3.9 and the wavelength range was 393-399 $\mathrm{nm}$. $\mathrm{Fe}^{2+}$-EDTA was prepared by mixing standard $\mathrm{Fe}^{2+}$ and $\mathrm{Na}_{2}$ EDTA solutions (molar ratio 1:1) and adding few drops of concentrated sulfuric acid. The calibration curves of $\mathrm{Fe}^{2+}$-EDTA were obtained by repeating the same procedure at the $270-330 \mathrm{~nm}$ wavelength range.

2.3.2 Determination of concentrations of Fe species. Samples of 10-15 mL were taken quickly from the side syringe of the reactor into a number of small test tubes as soon as $30 \mathrm{~s}$ and at subsequent allowable intervals for up to about $1 \mathrm{~h}$. Each of the samples was then diluted from one-half up to one- $128^{\text {th }}$ of the original strength. For the $\mathrm{Fe}^{2+}$ and $\left(\mathrm{Fe}^{2+}+\mathrm{Fe}^{3+}\right)$ determination 1 , 
10-phenanthroline was added to the samples, and absorbance was measured in the range of 506$512 \mathrm{~nm}$ and 393-399 nm, respectively. For Fe ${ }^{2+}$-EDTA determination, absorbance was measured directly with the spectrophotometer in the range of $270-330 \mathrm{~nm}$, where the molar extinction coefficients are significant.[40, 41] From these absorbance data, and using the previously determined calibration curves, the concentrations of $\mathrm{Fe}^{2+}, \mathrm{Fe}^{3+}$ and Fe-EDTA were recorded. Finally, the respective concentration values were multiplied by their respective dilution factors, and then averaged to determine the concentration of a particular sample. The concentration profiles of the species were then obtained. It should be noted that the persulfate anion by itself is not expected to interfere with these measurements in these wavelength ranges.[42]

\section{RESULTS AND DISCUSSION}

Based on the results of a previous study, different NO inlet concentrations (500-1000 ppm) have no significant effects on NO removal using $0.10 \mathrm{M} \mathrm{Na}_{2} \mathrm{~S}_{2} \mathrm{O}_{8}$, found to be the optimum concentration for aqueous removal and fractional conversion of NO.[6] As a result, $753 \mathrm{ppm}$ inlet NO concentration was used for this study as it is the average NO concentration in typical industrial flue gases. Several sets of absorption-oxidation experiments at several temperatures $\left(23,30,40,50,60\right.$ and $70\left( \pm 1^{\circ} \mathrm{C}\right)$ and $\mathrm{Na}_{2} \mathrm{~S}_{2} \mathrm{O}_{8}(0.1 \mathrm{M}( \pm 0.5 \%))$ were conducted in the absence and presence of $\mathrm{Fe}^{2+}(0.005-0.02 \mathrm{M}( \pm 0.5 \%))$ and $\mathrm{Na}_{2}$-EDTA $(0.005-0.03 \mathrm{M}( \pm 0.5 \%))$ at pH near neutral to acidic region $\mathrm{pH}$ of about 6.5). Experiments were also conducted at $50{ }^{\circ} \mathrm{C}$ in the $\mathrm{pH}$ range of 2.0 - 12.0 to evaluate the $\mathrm{pH}$ effects on NO removal. From the FTIR's EFCM recorded data, outlet gas concentration-time profiles were obtained and using the initial and final steady state value of NO concentration, percent conversion of NO is defined as

$\mathrm{X}_{\mathrm{NO}}=\frac{[\mathrm{NO}]_{\text {in }}-[\mathrm{NO}]_{\mathrm{out}}}{[\mathrm{NO}]_{\text {in }}} \times 100 \%$ 
where $[\mathrm{NO}]_{\text {in }}$ and $[\mathrm{NO}]_{\text {out }}$ are the steady state concentration in parts per million (ppm) of $\mathrm{NO}$ at the inlet and outlet of the reactor, respectively. The steady state outlet concentrations of NO were calculated by averaging the values of the outlet concentration after $3000 \mathrm{~s}$. It should also be noted that the concentration-time profiles show the characteristic initial sharp drop in NO exit concentration due to absorption in an unsaturated solutions, and mixing and dilution effects of the purge gas (i.e., $\mathrm{N}_{2}$ filling the void above the liquid level in the column), which was also observed and discussed in previous studies.[3, 6, 8]

3.1. Determination of Optimum $\mathrm{Fe}^{2+} /$ EDTA Ratio. The optimum molar ratio for $\mathrm{Fe}^{2+} /$ EDTA has been investigated and widely reported in the literature to be around 1:1 in the removal of organic and inorganic pollutants.[31] $\mathrm{Fe}^{2+}$ and EDTA react with one another according to the reversible reaction presented in eq 18.

$F e^{2+}+\mathrm{EDTA}^{2-} \stackrel{\mathrm{K}_{18}}{\Leftrightarrow} F e^{2+}-E D T A$

The kinetics of this reversible reaction fixes the amount of $\mathrm{Fe}^{2+}$-EDTA produced in the solution. The $\mathrm{Fe}^{2+} /$ EDTA molar ratio of $1: 1$ is desirable according to the stoichiometry of this reaction, but, a different molar ratio other than 1:1 has also been observed, when $\mathrm{Fe}^{2+}$-EDTA is used with other reagents in a combined NO absorption process.[43] Because, aqueous $\mathrm{Fe}^{2+}$-EDTA with persulfate is being studied for the very first time for the absorption of NO, the optimum molar ratio of $\mathrm{Fe}^{2+}$ and EDTA was deemed necessary to be determined experimentally.

The influence of $0.01 \mathrm{M} \mathrm{Fe}^{2+}$ (with no EDTA), and with various EDTA concentration levels $\left(0,0.005,0.01,0.015,0.02,0.025\right.$, and $0.03 \mathrm{M}$ or $\mathrm{Fe}^{2+}$-EDTA molar ratios of 2.00, 1.00, $0.667,0.500,0.400$, and 0.333$)$ on $\mathrm{NO}$ concentration profiles for three temperatures $(40,50$, and $60{ }^{\circ} \mathrm{C}$ ) is shown in Figure 2. At lowest temperature of $40{ }^{\circ} \mathrm{C}$ (Figure 2a) the concentration profiles were smooth and steady, while at $50{ }^{\circ} \mathrm{C}$ and $60{ }^{\circ} \mathrm{C}$ (Figure $2 \mathrm{~b}$ and $2 \mathrm{c}$, respectively), the 
results were not as stable, suggesting higher activation and greater interaction between reaction species at the higher temperatures. For a better interpretation of the effect of EDTA concentration and $\mathrm{Fe}^{2+}$-EDTA molar ratios, the respective $\mathrm{NO}$ percent conversion results are plotted as a function of EDTA concentration in Figure 3 for the different temperatures. At all three different temperatures, the NO conversion values showed an increase up to 0.01 M EDTA concentration, beyond which they decrease steadily with the increase in EDTA concentration, clearly demonstrating that the $1: 1 \mathrm{Fe}^{2+}$-EDTA molar ratio as optimal at all three temperatures. These results also show improved NO removal efficiencies using the combined persulfate- $\mathrm{Fe}^{2+}$ EDTA system compared to persulfate-Fe ${ }^{2+}$ process without EDTA.

Recently, Adewuyi and Sakyi reported the results of the simultaneous temperature and $\mathrm{Fe}^{2+}$ activation of aqueous persulfate for use in NO removal.[5] It was shown that NO conversion at all temperatures in or without the presence of $\mathrm{Fe}^{2+}$ increased sharply with persulfate concentration up to about $0.10 \mathrm{M}$ before leveling off, and $0.10 \mathrm{M} \mathrm{Na}_{2} \mathrm{~S}_{2} \mathrm{O}_{8}$ and $0.01 \mathrm{M} \mathrm{Fe}^{2+}$ were established as optimum concentrations for the process. NO fractional conversions of up to $79 \%$ and approximately $100 \%$ were observed at 70 and $90{ }^{\circ} \mathrm{C}$, respectively, including the $\sim 10 \%$ further improvement attributable to the $\mathrm{Fe}^{2+}$ activation at all temperatures. [5] As shown in Figure 3, NO conversion increases with increase in EDTA concentration up to $0.01 \mathrm{M}$ before decreasing with the additional increase in EDTA. At $40{ }^{\circ} \mathrm{C}$, it is seen that even for $0.03 \mathrm{M}$ EDTA the NO conversion (61.62\%) does not drop below the conversion level of no EDTA (i.e., 0.01 M $\mathrm{Fe}^{2+}$ only, $0.00 \mathrm{M}$ EDTA), that is, 52.99\%. But at 50 and $60{ }^{\circ} \mathrm{C}$ at $0.03 \mathrm{M}$ EDTA, NO conversions are $67.45 \%$ and $78.13 \%$ respectively, which are much lower than the case of without EDTA, which are $71.45 \%$ and $82.07 \%$ respectively, suggesting that at higher temperatures excess EDTA may have antagonistic effects on NO removal. The results in Figures 2 and 3 and 
Table 1 also clearly show that the optimum molar ratio for $\mathrm{Fe}^{2+}$ and EDTA needed with $0.1 \mathrm{M}$ persulfate for the combined persulfate- $\mathrm{Fe}^{2+}$-EDTA process is 1:1 (i.e., $0.01 \mathrm{M} \mathrm{Fe}^{2+}$ and $0.01 \mathrm{M}$ $\mathrm{Na}_{2}$-EDTA). As indicated before from prior literature studies, $\mathrm{Fe}^{2+}$-EDTA absorbs $\mathrm{NO}$ by a reversible binding producing nitrosyl compound as presented in eq 19. [25-28, 43, 44]

$F e^{2+}-E D T A+\mathrm{NO} \stackrel{\mathrm{K}_{19}}{\Leftrightarrow} F e^{2+}-E D T A(N O) ;$

$\mathrm{K}_{19}=3.6 \times 10^{6}\left(25^{\circ} \mathrm{C}\right), 6 \times 10^{5} \mathrm{M}^{-1}\left(50^{\circ} \mathrm{C}\right)$

$\mathrm{Fe}^{2+}$ not only reacts with EDTA according to reaction 18 to produce $\mathrm{Fe}^{2+}$-EDTA, which is then combines with $\mathrm{NO}$ in reaction 19 , but $\mathrm{Fe}^{2+}$ also activates persulfate in the solution as shown in reaction 5. The results suggest that at higher EDTA doses, EDTA depletes $\mathrm{Fe}^{2+}$ to the point of significantly lowering the amount of $\mathrm{Fe}^{2+}$ available for persulfate activation. From Figure 3, it can be seen that the absorption capability of the solution for NO did not drop drastically but instead a gradual decrease was observed at a given temperature, indicating that excess EDTA mainly affects iron activation of persulfate by scavenging available $\mathrm{Fe}^{2+}$, but not the temperature activation of persulfate to any significant extent.

\subsection{Synergistic Effect of $\mathrm{Fe}^{2+}$-EDTA with Persulfate, and Temperature Effect on}

NO Removal. Using the optimal concentrations of persulfate $(0.1 \mathrm{M}), \mathrm{Fe}^{2+}(0.01 \mathrm{M})$, and molar ratio of $\mathrm{Fe}^{2+}$-EDTA (1:1) established for NO removal, the effect of the $\mathrm{Fe}^{2+}$-EDTA addition was compared to the temperature-only and temperature- $\mathrm{Fe}^{2+}$ activated persulfate systems. A prior study of the effects of the different injection methods of $\mathrm{Fe}^{2+}$ and persulfate on the absorption of NO in a bubble column concluded that both persulfate and $\mathrm{Fe}^{2+}$ simultaneously introduced at the top of the reactor at the beginning of reaction gave the best NO removal efficiencies.[5] Because EDTA reacts with $\mathrm{Fe}^{2+}$ by reaction $18, \mathrm{Fe}^{2+}$ solution was first added to the de-oxygenated water 
followed by $\mathrm{Na}_{2}$-EDTA solution. Upon the complete reaction between $\mathrm{Fe}^{2+}$ and EDTA, persulfate is added from the top of the reactor. The reversible nature of the reaction presented in eq 18, dictates the presence of $\mathrm{Fe}^{2+}$, EDTA and $\mathrm{Fe}^{2+}$-EDTA in the solution, and enough $\mathrm{Fe}^{2+}$ is expected to remain in the solution for persulfate activation. Figure 4 showing the NO concentration profile at $30^{\circ} \mathrm{C}$, compares the NO removal efficiency of the combined persulfate$\mathrm{Fe}^{2+}$-EDTA system to those of persulfate only and persulfate with $\mathrm{Fe}^{2+}$. The conversion for 0.1 $\mathrm{M}$ persulfate only at $30{ }^{\circ} \mathrm{C}$ is about $25.13 \%$. The addition of $0.01 \mathrm{M} \mathrm{Fe}^{2+}$ increases the conversion up to $30.81 \%$, a $5.68 \%$ increase in the $\mathrm{NO}$ removal efficiency. When $0.01 \mathrm{M} \mathrm{Fe}^{2+}$ and $0.01 \mathrm{M}$ EDTA are added to $0.1 \mathrm{M}$ persulfate solution, the fractional conversion is $55.64 \%$, an additional $24.83 \%$ increase in NO removal efficiency. Figure 5 illustrates the comparison of NO concentration profiles at six different temperatures $\left(23,30,40,50,60\right.$ and $\left.70{ }^{\circ} \mathrm{C}\right)$ of the results of persulfate activated by $\mathrm{Fe}^{2+}$ ion and by the combined $\mathrm{Fe}^{2+}$-EDTA. The addition of $0.01 \mathrm{M}$ EDTA increases NO conversion efficiency by almost $28 \%$ at $23{ }^{\circ} \mathrm{C}$, while at $30{ }^{\circ} \mathrm{C}$, the conversion increases by almost 25\%. As shown in Figure 5, the NO conversion increases by approximately $13,7,5$, and $4 \%$ at $40,50,60$, and $70{ }^{\circ} \mathrm{C}$, respectively.

In Figure 6, the NO conversion in the temperature range of $23-70{ }^{\circ} \mathrm{C}$ is compared for the three absorptive systems, where NO fractional conversion data for the persulfate-only system were taken from our previous work.[6] It can be seen that, at higher temperature, the increase in NO removal efficiency due to the presence of 0.01 M EDTA become less significant but maintains a higher value with increase in temperature. As a result, close to $100 \% \mathrm{NO}$ removal is obtained at $70{ }^{\circ} \mathrm{C}$ compared with the $\mathrm{Fe}^{2+}$ activated persulfate system, which requires up to $90{ }^{\circ} \mathrm{C}$ for the same level of NO removal efficiency.[5] It is observed that the effectiveness of the NO removal is temperature-dependent, gradually diminishing from the lower temperature (28\% at 23 
$\left.{ }^{\circ} \mathrm{C}\right)$ to higher temperature $\left(4 \%\right.$ at $\left.70{ }^{\circ} \mathrm{C}\right)$. This could be attributed to the reversible binding of NO with $\mathrm{Fe}^{2+}$-EDTA in reaction 19. As indicated from prior literature, the forward reaction constant, $\mathrm{k}_{19}$ is higher in the lower temperature $\left(6 \times 10^{7} \mathrm{M}^{-1} \mathrm{~s}^{-1}\right.$ at $\left.25^{\circ} \mathrm{C}\right)$ compared to the value at the higher temperature $\left(3.7 \times 10^{7} \mathrm{M}^{-1} \mathrm{~s}^{-1}\right.$ at $\left.50{ }^{\circ} \mathrm{C}\right)$. At $50{ }^{\circ} \mathrm{C}$, the backward reaction constant, $\mathrm{k}_{-19}$ increases from 6 to $60 \mathrm{~s}^{-1}$, resulting in a lower value of equilibrium constant $\mathrm{K}_{19}$ at the higher temperature.[43] However, the comparative advantage still holds (around 5\% higher NO conversion at $70{ }^{\circ} \mathrm{C}$ ) due to the synergistic effect of $\mathrm{Fe}^{2+}$-EDTA on persulfate oxidation of NO. Because at $23{ }^{\circ} \mathrm{C}$, NO removal increased by almost $30 \%$ and at $70{ }^{\circ} \mathrm{C}$ by $4-5 \%$ and the $\mathrm{Fe}^{2+}-$ EDTA reversible binding with NO (reaction 19) is slower at higher temperature as backward reaction rate increases, it should be expected that there will be little or no increase in NO removal. However, the NO removal increased instead by almost $4 \%$. This can be attributed to the comparative advantage of using $\mathrm{Fe}^{2+}$-EDTA over $\mathrm{Fe}^{2+}$ only activated persulfate. It has been reported in the literature that iron chelating prevents or minimizes the scavenging of hydroxyl radical, and hence, prevents suppression of Fenton or Fenton-like reactions.[36] Thus, in reactions 14 and 15 , where $\mathrm{Fe}^{2+}$ was responsible for the scavenging of hydroxyl and sulfate radicals, such reactions are suppressed when $\mathrm{Fe}^{2+}$-EDTA is used instead of $\mathrm{Fe}^{2+}$ only. In 2004, Liang et al.[33], in their study on the destruction of TCE using persulfate, concluded that the chelated iron compound is far superior to unchelated $\mathrm{Fe}^{2+}$ in persulfate activation. The superiority of $\mathrm{Fe}^{2+}$-EDTA over $\mathrm{Fe}^{2+}$ as a persulfate activator was also confirmed by ESR spectroscopy and probe compounds investigation to track different free radicals.[34] As shown in Figure 6, the $\mathrm{Fe}^{2+}$ activated persulfate system gives higher NO removal at higher temperature compared to persulfate only system, which is due to the higher activation of persulfate at higher temperature. The difference between NO removals of $\mathrm{Fe}^{2+}$-EDTA activated persulfate system 
and the persulfate-only system is almost the same at every temperature (i.e., 35-40\%). It could be deduced that activation effect from the presence of $\mathrm{Fe}^{2+}$-EDTA is about $5 \%$ and the remaining $22-25 \%$ increase is due to the direct absorption of $\mathrm{Fe}^{2+}$-EDTA. It has also been reported that NO bounds to $\mathrm{FeSO}_{4}$ in solution according to reaction 20.[27] However, the order of magnitude of the reaction constant is four times less than that of reaction 19.

$\mathrm{FeSO}_{4}+\mathrm{NO} \stackrel{\mathrm{K}_{20}}{\Leftrightarrow} \mathrm{Fe}(\mathrm{NO}) \mathrm{SO}_{4}$

Reaction 20 is relatively very slow compared to reaction 19 and considered insignificant in the removal of $\mathrm{NO}$ by the $\mathrm{Fe}^{2+}$-EDTA only system, nonetheless, it can play a significant role in combined persulfate and $\mathrm{Fe}^{\mathrm{II}}$-EDTA systems. In $\mathrm{Fe}^{2+}$-activated persulfate system, all the $\mathrm{Fe}^{2+}$ reacts very quickly and remains virtually non-existent in the solution and the possibility of reaction 20 is negligible to nil. However, in the combined persulfate and $\mathrm{Fe}^{2+}$-EDTA systems, the concentration of $\mathrm{Fe}^{2+}$ is determined by the equilibrium reaction in eq 19 (measured by spectrophotometric method) and the possibility of reaction 20 is reinvigorated and could aid the removal efficiency of NO.

As noted earlier, $\mathrm{O}_{2}$ in the flue gas continuously oxidizes the $\mathrm{Fe}^{2+}$ in the coordinated EDTA during the NO absorption process by $\mathrm{Fe}^{2+}$-EDTA, producing inert $\mathrm{Fe}^{3+}$-EDTA by reaction in eq 21.[43]

$$
\begin{aligned}
& 4 \mathrm{Fe}^{2+}-\mathrm{EDTA}+\mathrm{O}_{2}+2 \mathrm{H}_{2} \mathrm{O} \stackrel{k_{21}}{\rightarrow} 4 \mathrm{Fe}^{3+}-E D T A+4 O H^{-} \\
& \mathrm{k}_{19}=1.09 \times 10^{4} \mathrm{e}^{\left(-\frac{2.33 \times 10^{4}}{\mathrm{RT}}\right)}
\end{aligned}
$$

Because the ferric complex does not react with NO, the suppression of this undesired oxidation processes is currently a very important technological problem to be overcome. As stated earlier, a number of methods have been adopted to regenerate $\mathrm{Fe}^{2+}$-EDTA to sustain the NO removal using reductive agents such as sulfite $\left(\mathrm{SO}_{3}{ }^{2-}\right)$ and dithionite $\left(\mathrm{S}_{2} \mathrm{O}_{4}{ }^{2-}\right)$ ions.[26] In 1988 , Sada et 
al.[45] studied this reaction system and found it to be first order in $\mathrm{O}_{2}$ and half order in $\mathrm{Fe}^{2+}$ EDTA, and that the reaction could be suppressed by as much as $20 \%$ by the addition of excess $\mathrm{Fe}^{2+}$-EDTA. In our experiment water was de-aerated completely by purging with dry nitrogen before starting the $\mathrm{NO}$ absorption experiment, and also $\mathrm{Fe}^{2+}$ and $\mathrm{Na}_{2}$-EDTA were added to the system separately without producing $\mathrm{Fe}^{2+}$-EDTA outside the reactor. Therefore, the system remained completely oxygen free throughout the experiments to avoid or minimize the possibility of reaction 19 . Moreover, there was no $\mathrm{O}_{2}$ that could be determined in the FTIR's inlet and outlet spectra and no $\mathrm{Fe}^{3+}$-EDTA found in spectrophotometric determination of iron species. The goal here at this stage of the study is to understand the chemistry of the combined $\mathrm{Na}_{2} \mathrm{~S}_{2} \mathrm{O}_{8}$ and $\mathrm{Fe}^{2+}$-EDTA process without the complexity introduced by the presence of $\mathrm{O}_{2}$.

It has been reported in the literature that $\mathrm{Fe}^{2+}$-EDTA also reacts with $\mathrm{NO}_{2}^{-}$and $\mathrm{NO}_{2}$ by reaction presented in eqs 22 and 23, respectively, producing both $\mathrm{Fe}^{2+}$-EDTA(NO) and $\mathrm{Fe}^{3+}$ EDTA.[43, 46]

$2 \mathrm{Fe}^{2+}-\mathrm{EDTA}+\mathrm{NO}_{2}^{-}+2 \mathrm{H}^{+} \stackrel{\mathrm{K}_{22}}{\Longleftrightarrow} \mathrm{Fe}^{2+}-\mathrm{EDTA}(\mathrm{NO})+\mathrm{Fe}^{3+}-\mathrm{EDTA}+\mathrm{H}_{2} \mathrm{O}$

$2 \mathrm{Fe}^{2+}-\mathrm{EDTA}+2 \mathrm{NO}_{2} \stackrel{\mathrm{K}_{23}}{\Leftrightarrow} \mathrm{Fe}^{2+}-\mathrm{EDTA}(\mathrm{NO})+\mathrm{Fe}^{3+}-\mathrm{EDTA}+\mathrm{NO}_{3}^{-}$

The denitrification of $\mathrm{Fe}^{2+}$-EDTA(NO) can be done in biological processes where ethanol acts as a electron donor compound but, $\mathrm{Fe}^{2+}$-EDTA can also acts an electron donor. It has been reported that denitrification using $\mathrm{Fe}^{2+}$-EDTA as an electron donor is chemical reaction rather than biological in nature, thus probable in our reaction system.[43, 47]

$2 \mathrm{Fe}^{2+}-\mathrm{EDTA}(\mathrm{NO})+2 \mathrm{Fe}^{2+}-E D T A+4 \mathrm{H}^{+} \stackrel{k_{24}}{\longrightarrow} 4 \mathrm{Fe}^{3+}-E D T A+\mathrm{N}_{2}+2 \mathrm{H}_{2} \mathrm{O}$

If these reactions were to occur in our system, and $\mathrm{Fe}^{2+}$-EDTA(NO) and $\mathrm{Fe}^{3+}$-EDTA are produced, the absorption capability of the solution would be expected to decrease with the progression of time. The success of an effective NO removal process by $\mathrm{Fe}^{2+}$-EDTA lies in the 
efficient reduction of $\mathrm{Fe}^{2+}$-EDTA(NO) and $\mathrm{Fe}^{3+}$-EDTA, and regeneration of $\mathrm{Fe}^{2+}$-EDTA into the system. Sulfate and other persulfate derived ions in our system can effectively accomplish this task. It has been reported in the literature that $\mathrm{HSO}_{3}^{-}$and/or $\mathrm{SO}_{3}^{2-}$ can be used to reduce $\mathrm{Fe}^{2+}-$ EDTA(NO) and $\mathrm{Fe}^{3+}$-EDTA in NO removal process.[27, 28, 44] It should also be noted that in a neutral medium $\mathrm{NO}_{2}{ }^{-}$could react with $\mathrm{Fe}^{3+}$-EDTA, serving as an electron donor to reduce it to $\mathrm{Fe}^{2+}$-EDTA as in eq 25, and thus aiding iron recycling to maintain persulfate activation.[48]

$\mathrm{Fe}^{3+}$-EDTA $+\mathrm{NO}_{2}^{-} \rightarrow \mathrm{Fe}^{2+}$-EDTA $+\mathrm{NO}_{2}$

On the basis of these studies, the following reactions involving sulfate anions are proposed in our system for the reduction of $\mathrm{Fe}^{2+}$-EDTA(NO) and $\mathrm{Fe}^{3+}$-EDTA back to $\mathrm{Fe}^{2+}$-EDTA.

$\mathrm{Fe}^{3+}-\mathrm{EDTA}+\mathrm{HSO}_{4}^{-} \stackrel{k_{26}}{\longrightarrow} \mathrm{Fe}^{2+}-\mathrm{EDTA}+\frac{1}{2} \mathrm{~S}_{2} \mathrm{O}_{8}^{2-}+\mathrm{H}^{+}$

$\mathrm{Fe}^{2+}-\mathrm{EDTA}(\mathrm{NO})+\mathrm{SO}_{4}^{2-} \stackrel{\mathrm{K}_{27}}{\Leftrightarrow} \mathrm{Fe}^{2+}-\mathrm{EDTA}(\mathrm{NO}) \mathrm{SO}_{4}^{2-}$

$\mathrm{Fe}^{2+}-\mathrm{EDTA}(\mathrm{NO})+2 \mathrm{HSO}_{4}^{-} \stackrel{\mathrm{K}_{28}}{\Leftrightarrow} \mathrm{Fe}^{2+}-\mathrm{EDTA}+\mathrm{SO}_{4}^{2-}+\mathrm{H}_{2} \mathrm{SO}_{5}+\frac{1}{2} \mathrm{~N}_{2}$

However, to the best of our knowledge, no kinetic study for these reactions has been conducted in the open literature and would need to be undertaken in future studies. With these hypothesized reduction reaction pathways (reactions 25-28), it could be implied that the persulfate system also helps $\mathrm{Fe}^{2+}$-EDTA chemistry, producing a complete synergistic and simultaneous relationship. Also, based on these potential pathways, eq 28 could also yield the Caro's acid, which is a known powerful oxidant for both $\mathrm{NO}_{\mathrm{x}}$ and $\mathrm{S}(\mathrm{IV})$ in the $\mathrm{pH}$ range of 6.5-8.5, with regeneration of $\mathrm{Fe}^{2+}$-EDTA.[3] The results of prior studies on NO removal by $\mathrm{Fe}^{2+}$-EDTA only solution indicate that with the passage of time $\mathrm{Fe}^{2+}$-EDTA solution losses NO absorption capability and the NO conversion drops significantly as early as $2-3$ hours.[43] The long time viability of the absorbent solution was tested at $30{ }^{\circ} \mathrm{C}$ for both $\mathrm{Fe}^{2+}$-persulfate and the combined persulfate and $\mathrm{Fe}^{2+}$ EDTA processes. For the prolonged period of time $(6 \mathrm{~h})$, NO fractional conversion was found to 
be $28.07 \%$ for $\mathrm{Fe}^{2+}$ activated persulfate sytem and $56.88 \%$ for the combined persulfate and $\mathrm{Fe}^{2+}-$ EDTA system. The longtime viability of the combined solution to better sustain absorptionoxidation capability for $\mathrm{NO}$ suggests the possibility of continuous reduction of and both $\mathrm{Fe}^{3+}-$ EDTA and $\mathrm{Fe}^{2+}{ }_{-}-\mathrm{EDTA}(\mathrm{NO})$ to $\mathrm{Fe}^{2+}$-EDTA (with the formation of $\mathrm{N}_{2}$ in eq 28 as the reduction product of NO) such as the hypothesized reactions in eqs $25-28$, confirming the beneficial action of persulfate and its derived radicals and ions on $\mathrm{Fe}^{2+}$-EDTA at longtime period. As a result, close to $100 \%$ removal is obtained at $70{ }^{\circ} \mathrm{C}$ compared with the $\mathrm{Fe}^{2+}$ activated persulfate system, which requires up to $90{ }^{\circ} \mathrm{C}$ for the same level of NO removal.

\subsection{Effect of Initial $\mathrm{Fe}^{2+}$-EDTA Concentration and Temperature on NO Removal:}

The persulfate oxidation chemistry of NO in the presence of $\mathrm{Fe}^{2+}$-EDTA is complex, since it takes place through direct electron transfer from the persulfate anion, free radical reactions via the sulfate radical generated by activation, and the direct reaction of the NOx species with $\mathrm{Fe}^{2+}-$ EDTA, which results from the reversible reaction of $\mathrm{Fe}^{2+}$ and $\mathrm{EDTA}^{2-}$. Hence, the removal of the NO is also thought to be dependent on the consumption of the dissolved NO by the various reactive species in the liquid phase, which maintains the driving force needed for the absorption process. Figure 7 shows the synergistic and antagonistic aspects of the combined effects of increase in both the initial concentration of $\mathrm{Fe}^{2+}$-EDTA and temperature on NO removal. The graphs in Figure 7 show the effect of different $\mathrm{Fe}^{2+}$-EDTA concentration $(0.005$ to $0.05 \mathrm{M})$ on NO fractional conversion at the different temperatures $\left(23-70{ }^{\circ} \mathrm{C}\right)$. At all temperatures, NO conversion increases with increase in $\mathrm{Fe}^{2+}$-EDTA concentration up to $0.01 \mathrm{M}$, peaking at $96.28 \%$ at $70{ }^{\circ} \mathrm{C}$. However, as the $\mathrm{Fe}^{2+}$-EDTA concentration increases from $0.01 \mathrm{M}$ to $0.02 \mathrm{M}$, the $\mathrm{NO}$ conversion increases very slightly in the temperature range $23-40{ }^{\circ} \mathrm{C}$, but decreases from $50-60{ }^{\circ} \mathrm{C}$, while

with $\mathrm{Fe}^{2+}$-EDTA concentration of $0.02 \mathrm{M}$ at $70{ }^{\circ} \mathrm{C}$, the drop in $\mathrm{NO}$ removal is even more 
pronounced. With further increase in $\mathrm{Fe}^{2+}$-EDTA concentration to $0.05 \mathrm{M}$, its antagonistic effects on the aqueous persulfate removal of NO occurs at all temperatures except those at the lower temperatures of 23 and $30{ }^{\circ} \mathrm{C}$. The solution appears to completely lose its absorption capability for $\mathrm{NO}$ at the higher temperatures of 60 and $70{ }^{\circ} \mathrm{C}$ in the presence of $0.05 \mathrm{M} \mathrm{Fe}^{2+}-$ EDTA. These results are similar to those obtained with the use of excess $\mathrm{Fe}(\mathrm{II})$ concentration levels in the absence of EDTA.[5, 21]. The results appear to suggest that, while NO conversion increases with $\mathrm{Fe}^{2+}$-EDTA concentration at lower temperatures $\left(23\right.$ to $30{ }^{\circ} \mathrm{C}$ ) increases beyond $0.01 \mathrm{M}$ are detrimental at the higher temperatures $\left(40\right.$ to $\left.70{ }^{\circ} \mathrm{C}\right)$.

As indicated earlier in reactions (7-16), in addition to the direct oxidation of NO by persulfate, direct interactions of radicals generated from persulfate activation with $\mathrm{Fe}^{2+}$ and selfrecombination and intercombination of oxidative sulfate and hydroxyl free radicals reactions (15 - 16), which might tend to reduce $\mathrm{NO}_{\mathrm{x}}$ oxidation, could play a significant role depending on reaction conditions. Higher temperatures accelerate rate of activation and can result in very aggressive oxidizing conditions. At higher temperatures and in the presence of optimal amount of $\mathrm{Fe}^{2+}$-EDTA, the decomposition of persulfate is faster and so is the rate of generation of oxidative species. Also, it is well known that the hydroxyl radical also reacts with Fe-EDTA as in reactions 29 and 30 with rate constants (at about $\mathrm{pH}$ 6) ranging from $4.0 \times 10^{8}$ to $5.0 \times 10^{9} \mathrm{M}^{-}$ ${ }^{1} \mathrm{~s}^{-1} \cdot[49-51]$

$$
\begin{aligned}
& {[\mathrm{Fe}(\text { edta })]^{2-}+O H^{\bullet} \stackrel{k_{29}=4.0 \times 10^{8}-5.0 \times 10^{9} M^{-1} s^{-1}}{\longrightarrow}[\mathrm{Fe}(\text { edta })]^{-}+\mathrm{OH}^{-}} \\
& {[\mathrm{Fe}(\text { edta })]^{-}+\mathrm{OH}^{\bullet} \stackrel{k_{30}=5.2 \times 10^{8}-2.0 \times 10^{9} \mathrm{M}^{-1} \mathrm{~S}^{-1}}{\longrightarrow} \mathrm{H}_{2} \mathrm{O}+\text { products }}
\end{aligned}
$$


However, the $\mathrm{OH}^{\bullet}$ generated in reaction 6 is more likely to react with NO since reaction 7 is 10 100 times higher than reactions 29 and 30 at the optimal concentrations of $\mathrm{Fe}^{2+}$-EDTA and lower temperatures. Also, the $\mathrm{OH}^{\bullet}$ and $\mathrm{SO}_{4}^{--}$generated in reactions 5 and 6 are more likely to react directly with NO in reactions 7 and 8, and not other reactions. However, reactions 29 and 30 could be significant at higher $\mathrm{Fe}^{2+}$-EDTA concentrations and higher reaction temperatures. In addition, self-recombination $\left(\mathrm{SO}_{4}^{--} / \mathrm{SO}_{4}^{--}\right)$and intercombination of oxidative free radicals $\left(\mathrm{SO}_{4}^{--}\right.$ and $\left.O H^{\bullet}\right)$, resulting from higher production of sulfate radicals possibly due to the effects of higher temperatures, are also possible. The explanation is supported in part by the fact that the reaction between $\mathrm{OH}^{\bullet}$ and $\mathrm{NO}$ (reaction 7) is a factor of 100 faster than reaction between $\mathrm{OH}^{\bullet}$ with $\mathrm{Fe}^{2+}$ (reaction 13), and a factor of 10 faster than even its self-recombination reaction $\left(\mathrm{OH}^{\bullet}+\right.$ $\left.\mathrm{OH}^{\bullet} \rightarrow \mathrm{H}_{2} \mathrm{O}_{2}, \mathrm{k}=5.5 \times 10^{9} \mathrm{M}^{-1} \mathrm{~S}^{-1}\right)$. However, the scavenging reactions by $\mathrm{SO}_{4}^{\cdot-}$ and $\mathrm{OH}^{\bullet}$ could be significant at higher $\mathrm{Fe}^{2+}$ doses and temperatures and compete with the $\mathrm{SO}_{4}^{--} / \mathrm{NO}_{\mathrm{x}}$ reactions in solution. In addition, the presence of high levels of $\mathrm{Fe}^{2+}$ EDTA results in the pronounced scavenging of the $\mathrm{SO}_{4}^{--}$and/or $\mathrm{OH}^{\bullet}$ radicals and also the sulfate/bisulfate ions and radicals that are available for the reversible binding of $\mathrm{NO}$ to reduce the $\mathrm{Fe}^{3+} \mathrm{EDTA}$ back to $\mathrm{Fe}^{2+}$ EDTA. The combinative effects of these reactions could explain why where at lower $\mathrm{Fe}^{2+}{ }_{-}$ EDTA concentration, persulfate and $\mathrm{Fe}^{2+}$-EDTA act synergistically to boost the NO removal to an unprecedented level, but act completely antagonistically to each other at the higher $\mathrm{Fe}^{2+}$ EDTA concentration and higher temperature to significantly depletes the absorption capacity of the solution as observed in Figure 7.

3.4. Effect of $\mathbf{p H}$ on NO Removal: The effect of $\mathrm{pH}$ on NO removal by combined persulfate and $\mathrm{Fe}^{\mathrm{II}}$-EDTA system was investigated at $50^{\circ} \mathrm{C}$ (a temperature that mimics typical industrial flue gas inlet condition). Figure 8 illustrates the effect of different solution $\mathrm{pH}(2.0-12.0)$ on NO 
removal at $50{ }^{\circ} \mathrm{C}$ for the combined $\mathrm{Na}_{2} \mathrm{~S}_{2} \mathrm{O}_{8}(0.1 \mathrm{M})$ and $\mathrm{Fe}^{2+}$-EDTA $(0.01 \mathrm{M})$ system and comparison with our prior results showing $\mathrm{pH}$ effect on $\mathrm{NO}$ removal for $\mathrm{Na}_{2} \mathrm{~S}_{2} \mathrm{O}_{8}$-only system at the same concentration.[6] As seen in Figure 8, whereas there is no significant difference in NO removal with $\mathrm{pH}$ in the range 4-9 for the persulfate-only system; however, the combined persulfate and $\mathrm{Fe}^{\mathrm{II}}$-EDTA system shows optimal $\mathrm{pH}$ of around 6.5 for maximum of NO removal, with significantly improved removal efficiencies. It should also be noted that the typical $\mathrm{pH}$ limitation of $\mathrm{Na}_{2} \mathrm{~S}_{2} \mathrm{O}_{8}-\mathrm{Fe}^{2+}$ only system (operational $\mathrm{pH}$ of $\leq 3.5$, which is the drawback for using such a system for improving NO removal) is completely overcome by using $\mathrm{Fe}^{2+}$-EDTA instead of $\mathrm{Fe}^{2+}$ only with the persulfate solution. Adewuyi and Sakyi reported that acidic $\mathrm{pH}$ (3.0 to 4.0) is best for $\mathrm{Fe}^{2+}$ activated persulfate system as higher $\mathrm{pH}$ will result in $\mathrm{Fe}(\mathrm{OH})_{2}$ precipitate, which is severely detrimental to NO absorption.[5]

Persulfate is known to be highly reactive at low $\mathrm{pH}(<3)$, but it is also highly reactive at $\mathrm{pH}$ 's greater than 10.[16] Khan and Adewuyi (2010) studied the effects of pH on the persulfate-only oxidation and removal of NO and provided extensive discussions on the chemistry involving the roles of the persulfate anion and the generated sulfate and hydroxyl radicals resulting from its reactions in the 3-12 $\mathrm{pH}$ range.[6] It was concluded that a decrease in solution $\mathrm{pH}$ will accelerate the persulfate decomposition but will not produce an increase in the amount of reactive radicals generated, resulting in an insignificant change in $\mathrm{NO}$ absorption rate at low $\mathrm{pH}$; but that neutral to alkaline condition is much more effective in NO removal than acidic condition. This was attributed to the predominance of $\mathrm{OH}^{\bullet}$ as the oxidative radical at the high pHs. It was stated that since $O H^{\bullet}$ reacts with NO at almost diffusion controlled rate $\left(k=2 \times 10^{10} M^{-1} S^{-1}\right)$, the consumption of NO in the liquid phase was expected to be much higher at alkaline conditions 
than in an acidic one. However, it was noted that at very high $\mathrm{pH}$, the effectiveness might be reduced due to the rapid dissociation of $\mathrm{OH} \bullet$ in alkaline solutions as illustrated by eq. 31 .

$O H^{\bullet}+\mathrm{OH}^{-} \stackrel{k_{f}, k_{b}}{\Longleftrightarrow} \mathrm{O}^{\bullet-}+\mathrm{H}_{2} \mathrm{O}$

where $k_{f}=1.2 \times 10^{10} \mathrm{M}^{-1} \mathrm{~s}^{-1}$ for forward and $k_{b}=9.3 \times 10^{7} \mathrm{~s}^{-1}$ for backward reaction and the oxide radical ion $\left(\mathrm{O}^{\bullet-}\right)$ is known to react more slowly with the same substrate than $O H^{\bullet}$. Also, the effects of the competition for $\mathrm{OH}^{\bullet}$ and $\mathrm{SO}_{4}{ }^{-}$by the phosphate species in the buffer was discussed and it was concluded to be marginal in the $\mathrm{pH}$ region of $\mathrm{H}_{2} \mathrm{PO}_{4}{ }^{-}$and $\mathrm{HPO}_{4}{ }^{2-}$ used in the buffer system, hence, the impact on persulfate- $\mathrm{NO}_{\mathrm{X}}$ system was expected to be minimum. Liang and Bruell in 2004[52], also showed that phosphate-buffered systems (e.g. phosphate anion species) did not have significant effect on persulfate oxidation of trichloroethylene (TCE).

The effect of $\mathrm{pH}$ value on NO removal rate for the combined $\mathrm{Na}_{2} \mathrm{~S}_{2} \mathrm{O}_{8}$ and $\mathrm{Fe}^{2+}$-EDTA system can be explained by the impacts of $\mathrm{pH}$ on the complex formation constant of EDTA and ferrous iron. With pH changing, there may be four kinds of Fe and EDTA.[50] It can be represented by:

$\mathrm{FeHY}^{-} \stackrel{\mathrm{pH}=1}{\longrightarrow} \mathrm{FeHY}^{2-} \stackrel{\mathrm{pH}=6}{\longrightarrow} \mathrm{Fe}(\mathrm{OH}) \mathrm{Y}^{3-} \stackrel{\mathrm{pH}=9}{\longrightarrow} \mathrm{Fe}(\mathrm{OH})_{2} \mathrm{Y}^{4-} \stackrel{\mathrm{pH}=10.5}{\longrightarrow} \mathrm{Fe}(\mathrm{OH})_{2} \downarrow$

where $\mathrm{Y}$ is the EDTA ligand.

The $\mathrm{Fe}^{2+}$-EDTA and $\mathrm{Fe}^{3+}$-EDTA are reported to be the predominant species in the mid-pH range $(\mathrm{pH}>3.8<6.8)$. [53] The formation constants $(\operatorname{LogK})$ for the various complexation forms of $\mathrm{Fe}^{2+}$ and EDTA under the range of $\mathrm{pH}$ studied have been reported to be 2.8, 14.25, 4.87 and 4.1 at $\mathrm{pH} 1,6,9$, and 10.5, respectively. It can be concluded that the complex formation constant of $\mathrm{Fe}^{2+}$-EDTA reached the largest value at about $\mathrm{pH}$ of 6.0 . At more acidic or more alkaline solution, the complex formation constant becomes much smaller. This would explain the optimal 
and much improved NO removal obtained with the combined $\mathrm{Na}_{2} \mathrm{~S}_{2} \mathrm{O}_{8}$ and $\mathrm{Fe}^{2+}$-EDTA system at pH around 6.5. In addition, Dwibedy et al.[54] in 2000, reported rate constants of $O H^{\bullet}$ with acidbase conjugates of EDTA to be $1.8 \times 10^{9}, 1.2 \times 10^{9}, 5.0 \times 10^{8}, 3.3 \times 10^{9}$ and $5.7 \times 10^{9} \mathrm{M}^{-1} \mathrm{~s}^{-1}$, respectively, at $\mathrm{pH} 2\left(\mathrm{H}_{4} \mathrm{Y}\right), 3\left(\mathrm{H}_{3} \mathrm{Y}^{-}\right), 5\left(\mathrm{H}_{2} \mathrm{Y}^{2-}\right), 8\left(\mathrm{HY}^{3-}\right)$ and $11\left(\mathrm{Y}^{4-}\right)$. The data also suggest the the protonated $\mathrm{Fe}^{3+}$-EDTA and $\mathrm{Fe}^{2+}$-EDTA complexes predominant in the mid-pH range are less susceptible to $\mathrm{OH}^{\bullet}$ oxidation, which is in consistent with the result in Figure 8 indicating NO removal optimal in the the mid-pH range. The $\mathrm{OH}^{\bullet}$ is electrophilic in its reactions with with acids, and more strongly with amines; its rate of reaction is reduced when the substrate is protonated.[50]

3.5. Studies on Iron Speciation and Material Balance. The concentration of the iron species present in the solution $\left(\mathrm{Fe}^{2+}, \mathrm{Fe}^{3+}\right.$ and $\mathrm{Fe}^{2+}$-EDTA) is determined spectrophotometrically at $50{ }^{\circ} \mathrm{C}$ using $0.1 \mathrm{M}$ persulfate concentration and three different $\mathrm{Fe}^{2+}$ and $\mathrm{EDTA}\left(\mathrm{Fe}^{2+}: \mathrm{EDTA}=\right.$ 1:1) concentration, $0.005,0.010$ and $0.020 \mathrm{M}$, as discussed earlier. Total measured Fe is the sum of $\mathrm{Fe}^{2+}, \mathrm{Fe}^{3+}$ and $\mathrm{Fe}^{2+}$-EDTA and undetermined $\mathrm{Fe}$ is the difference between initial iron concentration and total measured iron. Figure 9 shows the profiles of all the iron species at 50 ${ }^{\circ} \mathrm{C}$. It can be seen from Figure 9 that $\mathrm{Fe}^{2+}$ concentration remains close to zero throughout the experiment suggesting near complete reaction with both persulfate and EDTA. The undetermined Fe consists of non-labile iron hydroxides, $\mathrm{Fe}^{2+}$-EDTA(NO) and other non-labile iron species presents in very small amounts. Because all other non-labile species except $\mathrm{Fe}^{2+}{ }_{-}$ EDTA(NO) remain essentially constant throughout the experiment, the increase in the undetermined $\mathrm{Fe}$ suggests increase in $\mathrm{Fe}^{2+}-\mathrm{EDTA}(\mathrm{NO})$ concentration, resulting from the progression of reaction 19 . Also, the $\mathrm{Fe}^{2+}$-EDTA(NO) concentration increases very slightly and slowly throughout the experiment, suggesting that its accumulation in the solution is very small. 
Hence, this would indicate its reduction back to $\mathrm{Fe}^{2+}$-EDTA by persulfate and radicals in the system, thus confirming the synergistic action of persulfate with $\mathrm{Fe}^{2+}$-EDTA.

The comparison between the concentration of iron species in $\mathrm{Fe}^{2+}$ activated persulfate system and combined persulfate and $\mathrm{Fe}^{2+}$-EDTA system is illustrated in Figure 10, and Table 1 shows the respective steady state maximum, minimum and average values. In Figure 10a, $\mathrm{Fe}^{2+}$ ion concentration is plotted for both of $\mathrm{Fe}^{2+}$ activated persulfate and persulfate with both $\mathrm{Fe}^{2+}$ and EDTA with initial concentrations of $0.005,0.01$ and $0.02 \mathrm{M}$. Ferrous ion concentration for both systems is similar, that is, upon addition of oxidant, $\mathrm{Fe}^{2+}$ concentration quickly diminishes to very low level indicating it has been oxidized to $\mathrm{Fe}^{3+}$ ion. Figure $10 \mathrm{~b}$ is plotted to observe the difference between the $\mathrm{Fe}^{2+}$ concentration profiles of the two processes more closely, and is a truncation of Figure 10a from $500 \mathrm{~s}$ to $4000 \mathrm{~s}$ to show the comparative $\mathrm{Fe}^{2+}$ concentration more clearly. As shown in Figure $10 \mathrm{~b}, \mathrm{Fe}^{2+}$ ion increases $\left(1 \times 10^{-5}\right.$ to $2.8 \times 10^{-4} \mathrm{M}$ on average) with the initial $\mathrm{Fe}^{2+}$ concentration $(0.005$ to $0.02 \mathrm{M})$ for $\mathrm{Fe}^{2+}$ activated persulfate systems. However, for combined persulfate and $\mathrm{Fe}^{2+}$-EDTA system, the concentration of $\mathrm{Fe}^{2+}$ remains the same $\left(1 \times 10^{-4}\right.$ $\mathrm{M}$ on average) for $0.005,0.010$ and $0.020 \mathrm{M}$ initial concentration. This can be explained by the reversible reaction in eq 18 , where, the forward and backward reactions stabilize $\mathrm{Fe}^{2+}$ concentration in the system that facilitates the $\mathrm{Fe}^{2+}$ activation of persulfate. Figure $10 \mathrm{c}$ shows the $\mathrm{Fe}^{3+}$ ion concentration profiles determined by 1,10 -phenanthroline method. Compared to $\mathrm{Fe}^{2+}$ activated persulfate system, $\mathrm{Fe}^{3+}$ ion concentration decreases significantly in the combined $\mathrm{Fe}^{2+}$ EDTA system during the absorption process. As shown in Table 1, the concentration of $\mathrm{Fe}^{3+}$ in $\mathrm{Fe}^{2+}$ activated persulfate systems is almost equal to sum of the concentration of $\mathrm{Fe}^{3+}$ and $\mathrm{Fe}^{2+}-$ EDTA in combined persulfate and $\mathrm{Fe}^{2+}$-EDTA systems. This implies that the addition of EDTA actually formed $\mathrm{Fe}^{2+}$-EDTA by taking up $\mathrm{Fe}^{2+}$ ion that are supposed to be converted into $\mathrm{Fe}^{3+}$ 
anyway, thus, the presence of EDTA increases the NO removal without necessarily affecting the persulfate activation by temperature and $\mathrm{Fe}^{2+}$, further confirming that $\mathrm{Fe}^{2+}$-EDTA does not suppress persulfate activation as discussed earlier. Figure $10 \mathrm{~d}$ shows the concentration profile for undetermined $\mathrm{Fe}$ species. In the persulfate systems with only $\mathrm{Fe}^{2+}$ the undetermined $\mathrm{Fe}$ consists of only non-labile iron species. In combined persulfate and $\mathrm{Fe}^{2+}$-EDTA systems, undetermined $\mathrm{Fe}$ also consists of $\mathrm{Fe}^{2+}-\mathrm{EDTA}(\mathrm{NO})$ and $\mathrm{Fe}^{3+}$-EDTA. Because in the spectrophotometric determination significant amount of $\mathrm{Fe}^{3+}$-EDTA was never found, the difference between undetermined $\mathrm{Fe}$ concentration in the two systems is $\mathrm{Fe}^{2+}$-EDTA(NO) assuming that the concentration of the non-labile iron species remains the same for same initial $\mathrm{Fe}^{2+}$ concentration.[55] As shown Table 1, the $\mathrm{Fe}^{2+}$-EDTA(NO) concentration (difference between two systems) is $0.001 \mathrm{M}$. $\mathrm{Fe}^{2+}$-EDTA(NO) does not change when $\mathrm{Fe}^{2+}$-EDTA increased from 0.01 to $0.02 \mathrm{M}$, suggesting no further $\mathrm{NO}$ removal occurred for the increase in initial $\mathrm{Fe}^{2+}$ concentration from 0.01 to $0.02 \mathrm{M}$, thus, confirming previously chosen optimum $\mathrm{Fe}^{2+}$ concentration of $0.01 \mathrm{M}$. Again, presence of only $10 \%$ of initial $\mathrm{Fe}^{2+}$ as $\mathrm{Fe}^{2+}$-EDTA(NO) and absence of $\mathrm{Fe}^{3+}$-EDTA indicate the role sulfate ions play in the reduction of $\mathrm{Fe}^{2+}$-EDTA(NO) and $\mathrm{Fe}^{3+}$-EDTA is significant in the combined system as suggested earlier.

3.6 Some Perspectives on Solution Regeneration and Reaction Products. In the removal of NO with iron chelates, the nitrosyl complexes (i.e., nitrogen-sulfur or N-S compounds or intermediates such as sulfamate and amine sulfonate), formed from interaction between nitrite and bisulfate, are usually treated or converted to useful products. An important aspect of this process is the ability of nitrosyl complexes to regenerate the metal chelate (i.e., $\mathrm{Fe}^{3+}$-EDTA is reduced by $\mathrm{HSO}_{3}{ }^{-}$to produce $\mathrm{Fe}^{2+}$-EDTA and dithionate ion) in a scrubber system by reacting with absorbed $\mathrm{SO}_{2}$ in aqueous solutions with simultaneous production of sulfate and 
nitrogen species such as $\mathrm{N}_{2} \cdot \mathrm{N}_{2} \mathrm{O}$ has been observed in strong acid solutions, but which in $\mathrm{O}_{2}$ deficient solutions reacts with $\mathrm{H}_{2} \mathrm{O}$ to form $\mathrm{N}_{2}$ and $\mathrm{HNO}_{2}$ (that is subsequently oxidized to $\mathrm{HNO}_{3}$ ). Nitrates are not very toxic themselves compared to nitrites, and if treatment is necessary, practical full-scale processes include evaporation (or distillation), ion exchange, biological denitrification, reverse osmosis, and catalytic liquid-phase methods.[56, 57] In general, the N-S compounds can be removed from the scrubbing solution as alkaline-metal salt precipitates (e.g. potassium salt precipitates) of commercial value, $\mathrm{SO}_{3}{ }^{-} / \mathrm{SO}_{4}{ }^{2-}$ ions as calcium salts (gypsum) by reaction with lime/limestone, and sodium nitrite and nitrate can be manufactured by the addition of $\mathrm{NaOH}$.[55] The complex $\mathrm{Fe}^{2+}$-EDTA(NO) can be decomposed to regenerate $\mathrm{Fe}^{2+}$-EDTA and recover NO as a rich gas.[58] Also, Suchecki et al. in 2004, showed that the use of iron powder as a reducing agent has merit in that maximum concentration of $\mathrm{NO}_{3}^{-}$and $\mathrm{SO}_{4}{ }^{2-}$ in liquid absorbent can be automatically controlled by crystallization of ferric nitrate $\left(\mathrm{Fe}\left(\mathrm{NO}_{3}\right)_{3}\right)$ and ferric sulfate $\left(\mathrm{Fe}_{2}\left(\mathrm{SO}_{4}\right)_{3}\right)$. [59] Both $\mathrm{Fe}\left(\mathrm{NO}_{3}\right)_{3}(\mathrm{~s})$ and $\mathrm{Fe}_{2}\left(\mathrm{SO}_{4}\right)_{3}(\mathrm{~s})$ can be removed as the filter cake in the filtration unit. Most of the scrubbing liquors leaving the reducing tank or filtration units (which may still contain such ion species as free $\mathrm{Fe}^{2+}$, free $\mathrm{Fe}^{3+}, \mathrm{Fe}^{2+}$-EDTA, $\left[\mathrm{Fe}^{3+}\right.$-EDTA free EDTA, $\mathrm{NO}_{3}{ }^{-}, \mathrm{SO}_{4}{ }^{2-}$ and so forth) are recycled to the absorber. As noted recently by Liu and coworkers (2014), boiler flue gas contains large amounts of waste heat and the temperature is often more than $120{ }^{\circ} \mathrm{C}$. They suggested that this reservoir of waste heat from the boiler can completely provide the energy needed for thermal persulfate activation in their $\left(\mathrm{NH}_{4}\right)_{2} \mathrm{~S}_{2} \mathrm{O}_{8}$-only process to simultaneously oxidize $\mathrm{NO}, \mathrm{SO}_{2}$ and $\mathrm{Hg}^{0}$.[60] The resulting products, $\left(\mathrm{NH}_{4}\right)_{2} \mathrm{SO}_{4}$ and $\mathrm{NH}_{4} \mathrm{NO}_{3}$ (obtained by partial addition of ammonia to neutralize the $\mathrm{H}_{2} \mathrm{SO}_{4}$ and the $\mathrm{HNO}_{3}$ in mixed solution) could also be concentrated and crystallized by using the flue gas waste energy. A number of catalytic liquid-phase methods are also under development to remove both nitrates 
and nitrites using palladium $(\mathrm{Pd})$ to reduce them to $\mathrm{N}_{2}$. [61-63] Hence, the development of the combined $\mathrm{Na}_{2} \mathrm{~S}_{2} \mathrm{O}_{8}-\mathrm{Fe}^{2+}$-EDTA technology could make it possible to combine the environmentally friendly utilization of coal with the improvement of agricultural productivity via binary $\mathrm{N}+\mathrm{S}$ fertilizer supply from neutralization of sulfate/nitrate with ammonia to produce ammonium sulfate/ammonium nitrate and hence, converting the liability of pollution problem advantageously into assets. However, further studies are necessary in the future to better demonstrate the potential applications and cost benefits of the combined process. This is beyond the scope of the current study.

\section{CONCLUSION}

The simultaneous and synergistic action of persulfate and $\mathrm{Fe}^{2+}$-EDTA for the removal of NO is demonstrated along with the temperature effects $\left(23-70^{\circ} \mathrm{C}\right)$ in a bubble column reactor operated in semi-batch mode. Using $0.1 \mathrm{M} \mathrm{Na}_{2} \mathrm{~S}_{2} \mathrm{O}_{8}$ and $0.01 \mathrm{M} \mathrm{Fe}^{2+}$ previously determined as the best concentrations of $\mathrm{Na}_{2} \mathrm{~S}_{2} \mathrm{O}_{8}-\mathrm{Fe}^{2+}$ system for $\mathrm{NO}$ absorption and oxidation at different temperatures $\left(23-90^{\circ} \mathrm{C}\right)$, the molar ratio of $\mathrm{Fe}^{2+}$ and EDTA was found to be $1: 1$ for maximum NO conversion in combined persulfate and $\mathrm{Fe}^{2+}$-EDTA process. The results showed significant improvement in NO removal compared with temperature-only and combined temperature-Fe ${ }^{2+}$ activated persulfate systems with almost $100 \% \mathrm{NO}$ conversion achieved at $70{ }^{\circ} \mathrm{C}$ compared to temperature and $\mathrm{Fe}^{2+}$-activated persulfate systems, which required a temperature $\geq 90{ }^{\circ} \mathrm{C}$ for the same conversion. This higher removal should provide a remarkable advantage in the treatment of industrial flue gas, which is generally received at the treatment plant in the temperature range of $50-70{ }^{\circ} \mathrm{C}$. Also, the percentage increases in $\mathrm{NO}$ removal for the $\mathrm{Na}_{2} \mathrm{~S}_{2} \mathrm{O}_{8}-\mathrm{Fe}^{2+}$-EDTA were dependent on temperature range, $25-30 \%$ and 5-10\% at the lower $\left(<40{ }^{\circ} \mathrm{C}\right)$ and higher $\left(>40{ }^{\circ} \mathrm{C}\right)$ 
temperatures, respectively. The absorption of $\mathrm{NO}$ decreases at very low or high $\mathrm{pH}$ and found to be optimal at near neutral $\mathrm{pH}(\sim 6.5)$, which should reduce the use of auxiliary chemical for $\mathrm{pH}$ adjustment. Also, a very high concentration of Fe ${ }^{\mathrm{II}}$-EDTA is detrimental to NO removal due to the antagonistic effects of $\mathrm{Fe}^{2+}$ and/or Fe ${ }^{\mathrm{II}}$-EDTA on persulfate activation and subsequent NO absorption.

In this study the material balance on the iron species $\left(\mathrm{Fe}^{2+}, \mathrm{Fe}^{3+}\right.$ and $\mathrm{Fe}^{2+}$-EDTA) was determined spectrophotometrically to understand the simultaneous and synergistic relationship between persulfate and $\mathrm{Fe}^{2+}$-EDTA on NO removal, and reaction pathways to better explain the results. However, this investigation also indicates a number of areas in which additional research is needed. These include $\mathrm{O}_{2}$ effects; mass-transfer reaction kinetics; determination of reactants, intermediates and final products in the complex chemical system (using ion chromatograph, IC and electron spin resonance, ESR, and other analytical methods) for more comprehensive material balance; and the regeneration of the scrubbing liquor. We are currently working on the effects of other flue gas constituents $\left(\mathrm{O}_{2}, \mathrm{SO}_{2}, \mathrm{CO}_{2}\right)$, and additional studies on the effects of persulfate and EDTA concentrations and $\mathrm{pH}$ at different temperatures, and the results will be reported in future publications.

\section{ACKNOWLEDGMENTS}

The authors wish to acknowledge the contribution of National Science Foundation (NSF) for the funding received via Grant CBET-0651811. We also thank Nana Y. Sakyi for assisting with some of the initial experiments. 


\section{REFERENCES}

[1] Power Plants, Pollution and Soot - Air Quality, Environmental Defense Fund: New York. http://www.edf.page.cfm?tagID=78 ( accessed 20 May, 2010.

[2] National Energy Technolgy Lab (NETL). Advanced NOx emissions control: Regulatory drivers; NETL: Pittsburgh, PA, 2010, htt://www.netl.doe.gov/[accessed June 11, 2010].

[3] Y.G. Adewuyi, S.O. Owusu, Aqueous absorption and oxidation of nitric oxide with oxone for the treatment of tail gases: Process feasibility, stoichiometry, reaction pathways, and absorption rate, Ind. Eng. Chem. Res. 42 (2003) 4084-4100.

[4] Y.G. Adewuyi, N.Y. Sakyi, Simultaneous absorption and oxidation of nitric oxide and sulfur dioxide by aqueous solutions of sodium persulfate activated by temperature, Ind. Eng. Chem. Res, 52 (2013) $11702-11711$.

[5] Y.G. Adewuyi, N.Y. Sakyi, Removal of nitric oxide by aqueous sodium persulfate simultaneously activated by temperature and $\mathrm{Fe}^{2+}$ in a lab-scale bubble reactor, Ind. Eng. Chem. Res. 52 (2013) 1468714697.

[6] N.E. Khan, Y.G. Adewuyi, Absorption and oxidation of nitric oxide (NO) by aqueous solutions of Sodium Persulfate in a Bubble Column Reactor, Ind. Eng. Chem. Res. 49 (2010) 8749-8760.

[7] A.J. Sweeney, Y.A. Liu, Use of simulation to optimize NOx abatement by absorption and selective catalytic reduction, Ind. Eng. Chem. Res. 40 (2001) 2618-2627.

[8] Y. Adewuyi, X. He, H. Shaw, W. Lolertpihop, Simultaneous absorption and oxidation of $\mathrm{NO}$ and $\mathrm{SO}_{2}$ by aqueous solutions of sodium chlorite, Chem. Eng. Commun., 174 (1999) 21-51.

[9] D. Thomas, S. Brohez, J. Vanderschuren, Absorption of dilute NOx into nitric acid solutions containing hydrogen peroxide, Process Saf. Environ. Prot., 74 (1996) 52-58.

[10] H. Chu, T.W. Chien, S.Y. Li, Simultaneous absorption of $\mathrm{SO}_{2}$ and $\mathrm{NO}$ from flue gas with KMnO4/NaOH solutions, The Science of The Total Environment, 275 (2001) 127-135.

[11] N.D. Hutson, R. Krzyzynska, R.K. Srivastava, Simultaneous removal of $\mathrm{SO}_{2}, \mathrm{NO}_{\mathrm{x}}$, and $\mathrm{Hg}$ from coal flue gas using a $\mathrm{NaClO}_{2}$-enhanced wet scrubber, Ind. Eng. Chem. Res. 47 (2008) 5825-5831. 
[12] T.-W. Chien, H. Chu, Removal of $\mathrm{SO}_{2}$ and $\mathrm{NO}$ from flue gas by wet scrubbing using an aqueous $\mathrm{NaClO}_{2}$ solution, J. Haz. Mat., 80 (2000) 43-57.

[13] Y.G. Adewuyi, N.E. Khan, Modeling the ultrasonic cavitation-enhanced removal of nitrogen oxide in a bubble column reactor, AIChE J, 58 (2012) 2397-2411.

[14] Y. Adewuyi, S. Owusu, Ultrasound-induced aqueous removal of nitric oxide from flue gases: Effects of sulfur dioxide, chloride, and chemical oxidant, J. Phys. Chem. A, 110 (2006) 11098-11107.

[15] S. Owusu, Y. Adewuyi, Sonochemical removal of nitric oxide from flue gases, Ind. Eng. Chem. Res, 45 (2006) 4475-4485.

[16] D.A. House, Kinetics and mechanism of oxidations by peroxydisulfate, Chem. Rev., 62 (1962) 185203.

[17] P. Wardman, Reduction potentials of one-electron couples involving free-radicals in aqeusous solution, J. Phys. Chem. Ref. Data, 18 (1989) 1637-1755.

[18] Y.G. Adewuyi, Sonochemistry in environmental remediation. 1. Combinative and hybrid sonophotochemical oxidation processes for the treatment of pollutants in water, Environ. Sci. Technol. 39 (2005) 3409-3420.

[19] Y.G. Adewuyi, Sonochemistry in environmental remediation. 2. Heterogeneous sonophotocatalytic oxidation processes for the treatment of pollutants in water, Environ. Sci. Technol. 39 (2005) 8557-8570. [20] The Interstate Technology and Regulatory Council (ITRC). Technical and regulatory for in situ chemical oxidation of contaminated soil and groundwater, $2^{\text {nd }}$ ed.; The Interstate Technology and Regulatory Council: Washington, DC, 2005; http://www.itreweb.org/.

[21] Y.G. Adewuyi, M.A. Khan, N.Y. Sakyi, Kinetics and modeling of the removal of nitric oxide by aqueous sodium persulfate simultaneously activated by temperature and $\mathrm{Fe}^{2+}$, Ind. Eng. Chem. Res. 53 (2013) 828-839.

[22] G.-D. Fang, D.D. Dionysiou, Y. Wang, S.R. Al-Abed, D.-M. Zhou, Sulfate radical-based degradation of polychlorinated biphenyls: Effects of chloride ion and reaction kinetics, J. Hazard. Materials, 227-228 (2012) 394-401. 
[23] G. V. Buxton, T. N. Malone, G. Arthur Salmon, Reaction of $\mathrm{SO}_{4}^{-}$with $\mathrm{Fe}^{2+}, \mathrm{Mn}^{2+}$ and $\mathrm{Cu}^{2+}$ in aqueous solution, J. Chem. Soc., Faraday Trans., 93 (1997) 2893-2897.

[24] X.-L. Long, Z.-L. Xin, M.-B. Chen, W.-D. Xiao, W.-K. Yuan, Nitric oxide absorption into cobalt ethylenediamine solution, Sep. and Purif. Technol. 55 (2007) 226-231.

[25] J.F. Demmink, I.C.F. van Gils, A.A.C.M. Beenackers, Absorption of nitric oxide into aqueous solutions of ferrous chelates accompanied by instantaneous reaction, Ind. Eng. Chem. Research, 36 (1997) 4914-4927.

[26] T.T. Suchecki, B. Mathews, H. Kumazawa, Kinetic study of ambient-temperature reduction of Fe(III)edta by $\mathrm{Na}_{2} \mathrm{~S}_{2} \mathrm{O}_{4}$, Ind. Eng. Chem. Res, 44 (2005) 4249-4253.

[27] E. Sada, H. Kumazawa, I. Kudo, T. Kondo, Individual and simultaneous absorption of dilute NO and $\mathrm{SO}_{2}$ in aqueous slurries of $\mathrm{MgSO}_{3}$ with $\mathrm{Fe}(\mathrm{II})-\mathrm{EDTA}$, Ind. Eng. Chem. Proc. Design and Develop 19 (1980) 377-382.

[28] E. Sada, H. Kumazawa, H. Hikosaka, A kinetic study of absorption of nitrogen oxide (NO) into aqueous solutions of sodium sulfite with added iron(II)-EDTA chelate, Ind. Eng. Chem. Fundl. 25 (1986) 386-390.

[29] P. van der Maas, S. Peng, B. Klapwijk, P. Lens, Enzymatic versus nonenzymatic conversions during the reduction of EDTA-chelated Fe(III) in BioDeNOx reactors, Environ. Sci. Technol. 39 (2005) 26162623.

[30] L. Gao, X.-H. Mi, Y. Zhou, W. Li, A pilot study on the regeneration of ferrous chelate complex in $\mathrm{NO}_{\mathrm{x}}$ scrubber solution by a biofilm electrode reactor. Bioresour Technol. 102 (2011) 2605-2609.

[31] Z.B. Wu, L. Wang, W.R. Zhao, Kinetic study on regeneration of Fe(II)EDTA in the wet process of NO removal, Chem. Eng. J. 140 (2008) 130-135.

[32] X.-L. Long, L. Yang, X.-w. Chou, C. Li, W.-k. Yuan, Reduction of [Fe(III)EDTA]- catalyzed by activated carbon modified with ammonia solution, Environ. Progr. Sustainable Energy, 33 (2014) 99-106.

[33] C. Liang, C.J. Bruell, M.C. Marley, K.L. Sperry, Persulfate oxidation for in situ remediation of TCE. II. Activated by chelated ferrous ion, Chemosphere, 55 (2004) 1225-1233. 
[34] M. Ahmad, A. Teel, O. Furman, J. Reed, R. Watts, Oxidative and reductive pathways in ironethylenediaminetetraacetic acid-activated persulfate systems, J. Environ. Eng. 138 (2012) 411-418.

[35] C. Liang, C.-P. Liang, C.-C. Chen, pH dependence of persulfate activation by EDTA/Fe(III) for degradation of trichloroethylene, J. Contaminant Hydrol. 106 (2009) 173-182.

[36] L. Li, Y. Abe, K. Kanagawa, T. Shoji, T. Mashino, M. Mochizuki, M. Tanaka, N. Miyata, Ironchelating agents never suppress Fenton reaction but participate in quenching spin-trapped radicals, Anal. Chim. Acta, 599 (2007) 315-319.

[37] N.E. Khan, Y.G. Adewuyi, A new method of analysis of peroxydisulfate using ion chromatography and its application to the simultaneous determination of peroxydisulfate and other common inorganic ions in a peroxydisulfate matrix, J. Chromatogr. A, 1218 (2011) 392-397.

[38] A.E. Harvey, J.A. Smart, E.S. Amis, Simultaneous spectrophotometric determination of iron(II) and total iron with 1,10-phenanthroline, Anal. Chem. 27 (1955) 26-29.

[39] V. Zang, M. Kotowski, R. Van Eldik, Kinetics and mechanism of the formation of Fe(II)(edta)NO in the system $\mathrm{Fe}(\mathrm{II})(\mathrm{edta}) / \mathrm{NO} / \mathrm{HONO} / \mathrm{NO}_{2}{ }^{-}$in aqueous solutions, Inorg. Chem. 27 (1988) 3279-3283.

[40] V. Zang, R. Van Eldik, Kinetics and mechanism of the autoxidation of iron(II) induced through chelation by ethylenediaminetetraacetate and related ligands, Inorg. Chem. 29 (1990) 1705-1711.

[41] Y. Kurimura, R. Ochiai, N. Matsuura, Oxygen Oxidation of Ferrous Ions Induced by Chelation, Bull. Chem. Soc. Japan, 41 (1968) 2234-2239.

[42] C.J. Liang, C.F. Huang, N. Mohanty, R.M. Kurakalva, A rapid spectrophotometric determination of persulfate anion in ISCO, Chemosphere, 73 (2008) 1540-1543.

[43] N. Liu, B.-H. Lu, S.-H. Zhang, J.-L. Jiang, L.-L. Cai, W. Li, Y. He, Evaluation of Nitric Oxide Removal from Simulated Flue Gas by Fe(II)EDTA/Fe(II)citrate Mixed Absorbents, Energy Fuels, 26 (2012) 4910-4916.

[44] M. Teramoto, S.-i. Hiramine, Y. Shimada, Y. Sugimoto, H. Teranishi, Absorption of dilute nitric monoxide in aqueous solutions of $\mathrm{Fe}(\mathrm{II})$-EDTA and mixed solutions of $\mathrm{Fe}(\mathrm{II})-\mathrm{EDTA}$ and $\mathrm{Na}_{2} \mathrm{SO}_{3}, \mathrm{~J}$. Chem. Eng. Japan. 11 (1977) 450-457. 
[45] E. Sada, H. Kumazawa, Y. Yoshikawa, Simultaneous removal of $\mathrm{NO}$ and $\mathrm{SO}_{2}$ by absorption into aqueous mixed solutions, AIChE J. 34 (1988) 1215-1220.

[46] H. Li, W. Fang, Kinetics of absorption of nitric oxide in aqueous iron(II)-EDTA solution, Ind. Eng. Chem. Res. 27 (1988) 770-774.

[47] P. van der Maas, L. Harmsen, S. Weelink, B. Klapwijk, P. Lens, Denitrification in aqueous FeEDTA solutions, J. Chem. Technol. Biotechnol. 79 (2004) 835-841.

[48] M. Jaworska, G. Stopa, Z. Stasicka, Photochemical NO-removal and $\mathrm{NO}_{\mathrm{x}}$-release in the presence of Fe-EDTA complexes. DFT calculations of electronic structure and spectroscopy of the $[\mathrm{Fe}(\mathrm{edta})(\mathrm{NO})]^{2-}$ complex, Nitric Oxide, 23 (2010) 227-233.

[49] J. Lati, D. Meyerstein, Oxidation of first-row bivalent transition-metal complexes containing ethylenediaminetetra-acetate and nitrilotriacetate ligands by free radicals: a pulse-radiolysis study, J. Chem. Soc, Dalton Trans, (1978) 1105-1118.

[50] B. Hobel, C. von Sonntag, OH-radical induced degradation of ethylenediaminetetraacetic acid (EDTA) in aqueous solution: a pulse radiolysis study, J. Chem. Soc, Perkin Trans 2, (1998) 509-514.

[51] G. Buxton, C. Greenstock, W. Helman, A. Ross, Critical review of rate constants for reactions of hydrated electrons, hydrogen atoms and hydroxyl radicals $(\bullet \mathrm{OH} / \bullet \mathrm{O})$ in aqueous solution, J. Phys. Chem. Ref. Data, 17 (1988) 513-886.

[52] C. Liang, C.J. Bruell, Thermally Activated Persulfate Oxidation of Trichloroethylene: Experimental Investigation of Reaction Orders, Ind. Eng. Chem. Res., 47 (2008) 2912-2918.

[53] K. Shimizu, R. Hutcheson, M.D. Engelmann, I. Francis Cheng, Cyclic voltammetric and aqueous equilibria model study of the $\mathrm{pH}$ dependant iron(II/III)ethylenediamminetetraacetate complex reduction potential, J. Electroanal. Chem. 603 (2007) 44-50.

[54] P. Dwibedy, G.R. Dey, D.B. Naik, K. Kishore, Rate constants for the reaction of OH radicals with some amino polycarboxylic acids, Intl J. Chem. Kinet. 32 (2000) 99-104.

[55] D. Littlejohn, S.G. Chang, Kinetic study of ferrous nitrosyl complexes, J. Phys. Chem. 86 (1982) 537-540. 
[56] G. Chang S, D. Littlejohn, H. Lin N, Kinetics of reactions in a wet flue gas simultaneous desulfurization and denitrification system. In: Flue Gas Desulfurization, Amer. Chem. Soc, 1982, pp. 127-152.

[57] L. Wang, W. Zhao, Z. Wu, Simultaneous absorption of $\mathrm{NO}$ and $\mathrm{SO}_{2}$ by Fe(II)EDTA combined with $\mathrm{Na}_{2} \mathrm{SO}_{3}$ solution, Chem. Eng. J. 132 (2007) 227-232.

[58] K.R. Jethani, N.J. Suchak, J.B. Joshi, Selection of reactive solvent for pollution abatement of $\mathrm{NO}_{\mathrm{x}}$, Gas Sep. Purif. 4 (1990) 8-28.

[59] T.T. Suchecki, B. Mathews, A.W. Augustyniak, H. Kumazawa, Applied kinetics aspects of ferric EDTA complex reduction with metal powder. Ind. Eng. Chem. Res. 58 (2014) 14234-14240.

[60] Y. Liu, Q. Wang, Removal of elemental mercury from flue gas by thermally activated ammonium persulfate in a bubble column reactor, Environ. Sci. Technol. 48 (2014) 12181-12189.

[61] A. Pintar, G. Bercic, J. Levec. Catalytic liquid-phase nitrite reduction: Kinetics and catalytic deactivation. AIChE J. 44 (1998) 2280-2292.

[62] A. Pintar, J. Batista, J. Levec, T. Kajiuchi. Kinetics of the catalytic liquid-phase hydrogenation of aqueous nitrate solutions. Appl. Catal. B: Environmental. 11 (1996) 81-98.

[63] A Pintar, J. Batista, J. Levec. Integrated ion exchange/catalytic process for efficient removal of nitrates from drinking water. Chem. Eng. Sci. 56 (2001) 1551-1559. 
Table 1. Iron species concentration for different initial $\mathrm{Fe}^{2+}$ and/or EDTA concentration with 0.1

M persulfate at $50{ }^{\circ} \mathrm{C}$

\begin{tabular}{|c|c|c|c|c|c|c|c|c|}
\hline \multirow[b]{2}{*}{ Iron Species' } & \multirow{2}{*}{\multicolumn{2}{|c|}{ Types of Values }} & \multicolumn{6}{|c|}{ Concentration $(\mathrm{M})$} \\
\hline & & & $\mathrm{Fe}^{2+}$ Only & $\begin{array}{l}\mathrm{Fe}^{2+} / \\
\text { EDTA }\end{array}$ & $\mathrm{Fe}^{2+}$ Only & $\begin{array}{l}\mathrm{Fe}^{2+} / \\
\text { EDTA }\end{array}$ & $\mathrm{Fe}^{2+}$ Only & $\begin{array}{l}\mathrm{Fe}^{2+} / \\
\text { EDTA }\end{array}$ \\
\hline \multicolumn{3}{|c|}{ Initial Concentration } & \multicolumn{2}{|c|}{0.005} & \multicolumn{2}{|c|}{0.01} & \multicolumn{2}{|c|}{0.02} \\
\hline \multirow{3}{*}{$\mathrm{Fe}^{2+}$} & \multirow{2}{*}{ Range } & Minimum & 0 & 0.000052 & 00008 & 0.000076 & .00012 & 0.000081 \\
\hline & & Maximum & $2.20 \times 10^{-5}$ & 0.000099 & 0.00022 & 0.00023 & 0.0005 & 0.00016 \\
\hline & \multicolumn{2}{|c|}{ Steady State Average } & $1.05 \times 10^{-5}$ & 0.000078 & 0.00013 & 0.00012 & 028 & 0.00011 \\
\hline \multirow{3}{*}{$\mathrm{Fe}^{3+}$} & \multirow[b]{2}{*}{ Range } & Minimum & 0.00457 & 0.00264 & 0.00929 & 0.00569 & 0.01838 & 0.01279 \\
\hline & & Maximum & 0.00494 & 0.00315 & 0.00986 & 0.00628 & 0.01918 & 0.01423 \\
\hline & \multicolumn{2}{|c|}{ Steady State Average } & 474 & 0.00286 & 00957 & 0.00599 & 884 & 0.01337 \\
\hline \multirow{3}{*}{$\mathrm{Fe}^{\mathrm{II}}$-EDTA } & \multirow[b]{2}{*}{ Range } & Minimum & & 0.00111 & & 0.00247 & & 0.00468 \\
\hline & & Maximum & & 0.00132 & & 0.00277 & & 0.0059 \\
\hline & \multicolumn{2}{|c|}{ Steady State Average } & & 0.00123 & & 0.00261 & & 0.00518 \\
\hline \multirow{3}{*}{$\begin{array}{c}\text { Total } \\
\text { Measured Fe }\end{array}$} & \multirow{2}{*}{ Range } & Minimum & 0.00458 & 0.00381 & 0.00937 & 0.0084 & 0.0185 & 0.01825 \\
\hline & & Maximum & 0.00495 & 0.0045 & 0.01 & 0.00919 & 0.01956 & 0.0194 \\
\hline & \multicolumn{2}{|c|}{ Steady State Average } & 0.00475 & 0.00416 & 0.00969 & 0.00872 & 0.01911 & 0.01866 \\
\hline \multirow{3}{*}{$\begin{array}{l}\text { Undetermined } \\
\text { Fe }\end{array}$} & \multirow{2}{*}{ Range } & Minimum & 0.00005 & 0.005 & 0 & 0.00031 & 0.00022 & 0.0011 \\
\hline & & Maximum & 0.00042 & 0.00119 & 0.00063 & 0.00151 & 0.00075 & 0.00175 \\
\hline & \multicolumn{2}{|c|}{ Steady State Average } & 0.00025 & 0.00084 & 0.00031 & 0.00128 & 0.00044 & 0.00144 \\
\hline
\end{tabular}




\section{Figure Caption}

Figure 1. Schematic diagram of the experimental set-up.

Figure 2. NO concentration profiles at 40,50 and $60{ }^{\circ} \mathrm{C}$ for $\mathrm{Na}_{2} \mathrm{~S}_{2} \mathrm{O}_{8}$ concentration of $0.1 \mathrm{M}$ and $\mathrm{Fe}^{2+}$ concentration of $0.01 \mathrm{M}$ for different $\mathrm{Na}_{2}$-EDTA concentration $(0-0.03 \mathrm{M})$ : (a) $40{ }^{\circ} \mathrm{C}$, (b) 50 ${ }^{\circ} \mathrm{C}$ and (c) $60{ }^{\circ} \mathrm{C}$.

Figure 3. NO fractional conversion at 40,50 and $60{ }^{\circ} \mathrm{C}$ for different $\mathrm{Na}_{2}$-EDTA concentration for $\mathrm{Na}_{2} \mathrm{~S}_{2} \mathrm{O}_{8}$ concentration of $0.1 \mathrm{M}$ and $\mathrm{Fe}^{2+}$ concentration of $0.01 \mathrm{M}$.

Figure 4. Comparative $\mathrm{NO}$ concentration profiles at $30{ }^{\circ} \mathrm{C}$ for $0.1 \mathrm{M} \mathrm{Na}_{2} \mathrm{~S}_{2} \mathrm{O}_{8}$ solution system, 0.1 $\mathrm{M} \mathrm{Na}_{2} \mathrm{~S}_{2} \mathrm{O}_{8}$ solution in presence of $0.01 \mathrm{M} \mathrm{Fe}^{2+}$, and $0.1 \mathrm{M} \mathrm{Na}_{2} \mathrm{~S}_{2} \mathrm{O}_{8}$ solution with $0.01 \mathrm{M}$ $\mathrm{Fe}^{2+}$ and $0.01 \mathrm{M} \mathrm{Na}_{2}$-EDTA.

Figure 5. Comparative $\mathrm{NO}$ concentration profiles for $0.1 \mathrm{M} \mathrm{Na}_{2} \mathrm{~S}_{2} \mathrm{O}_{8}$ solution in presence of $0.01 \mathrm{M} \mathrm{Fe}^{2+}$, and $0.1 \mathrm{M} \mathrm{Na}_{2} \mathrm{~S}_{2} \mathrm{O}_{8}$ solution with $0.01 \mathrm{M} \mathrm{Fe}^{2+}$ and $0.01 \mathrm{M} \mathrm{Na}_{2}$-EDTA at various temperature $\left(23-70{ }^{\circ} \mathrm{C}\right)$ : (a) 23, (b) 30, (c) 40, (d) 50, (e) 60 and (f) $70{ }^{\circ} \mathrm{C}$.

Figure 6. Dependence of $\mathrm{NO}$ fractional conversions on temperature $\left(23-70{ }^{\circ} \mathrm{C}\right)$ for $0.1 \mathrm{M}$ $\mathrm{Na}_{2} \mathrm{~S}_{2} \mathrm{O}_{8}$ solution system, $0.1 \mathrm{M} \mathrm{Na}_{2} \mathrm{~S}_{2} \mathrm{O}_{8}$ solution in presence of $0.01 \mathrm{M} \mathrm{Fe}^{2+}$, and $0.1 \mathrm{M}$ $\mathrm{Na}_{2} \mathrm{~S}_{2} \mathrm{O}_{8}$ solution with $0.01 \mathrm{M} \mathrm{Fe}^{2+}$ ion and $0.01 \mathrm{M} \mathrm{Na}_{2}$-EDTA.

Figure 7. Effect of different initial $\mathrm{Fe}^{2+}$-EDTA concentration $(0.0-0.05 \mathrm{M})$ and various temperatures $\left(23-70{ }^{\circ} \mathrm{C}\right)$ on $\mathrm{NO}$ removal in the presence of $0.1 \mathrm{M} \mathrm{Na}_{2} \mathrm{~S}_{2} \mathrm{O}_{8}$.

Figure 8. Effect of $\mathrm{pH}(2-12)$ on $\mathrm{NO}$ removal for the $0.1 \mathrm{M} \mathrm{Na}_{2} \mathrm{~S}_{2} \mathrm{O}_{8}$ solution in presence and absence of combined $0.01 \mathrm{M} \mathrm{Fe}^{2+}$ and $0.01 \mathrm{M} \mathrm{Na}_{2}$-EDTA at $50{ }^{\circ} \mathrm{C}$

Figure 9. Iron species $\left(\mathrm{Fe}^{2+} / \mathrm{Fe}^{3+} / \mathrm{Fe}^{\mathrm{II}}-\mathrm{EDTA} / \mathrm{Undetermined} \mathrm{Fe}\right)$ profiles at $50{ }^{\circ} \mathrm{C}$ for $0.1 \mathrm{M}$ $\mathrm{Na}_{2} \mathrm{~S}_{2} \mathrm{O}_{8}$ solution and different initial $\mathrm{Fe}^{2+} / \mathrm{Na}_{2}$-EDTA $\left(\mathrm{Fe}^{2+}:\right.$ EDTA=1:1) concentration: (a) 0.005 $\mathrm{M} \mathrm{Fe}^{2+} / \mathrm{Na}_{2}$-EDTA, (b) $0.01 \mathrm{M} \mathrm{Fe}^{2+} / \mathrm{Na}_{2}$-EDTA, and (c) $0.02 \mathrm{M} \mathrm{Fe}^{2+} / \mathrm{Na}_{2}-\mathrm{EDTA}$. 
Figure 10. Comparative $\mathrm{Fe}^{2+}$ and $\mathrm{Fe}^{3+}$ concentration profiles at $50{ }^{\circ} \mathrm{C}$ for $0.1 \mathrm{M} \mathrm{Na}_{2} \mathrm{~S}_{2} \mathrm{O}_{8}$ solution in presence of $0.01 \mathrm{M} \mathrm{Fe}^{2+}$, and $0.1 \mathrm{M} \mathrm{Na}_{2} \mathrm{~S}_{2} \mathrm{O}_{8}$ solution with $0.01 \mathrm{M} \mathrm{Fe}^{2+}$ and $0.01 \mathrm{M}$ $\mathrm{Na}_{2}$-EDTA: (a) $\mathrm{Fe}^{2+}$ profiles, (b) Truncated and enlarged $\mathrm{Fe}^{2+}$ profiles ( $\geq 500 \mathrm{~s}$ ), (c) $\mathrm{Fe}^{3+}$ profiles and (d) Undetermined-Fe profiles.

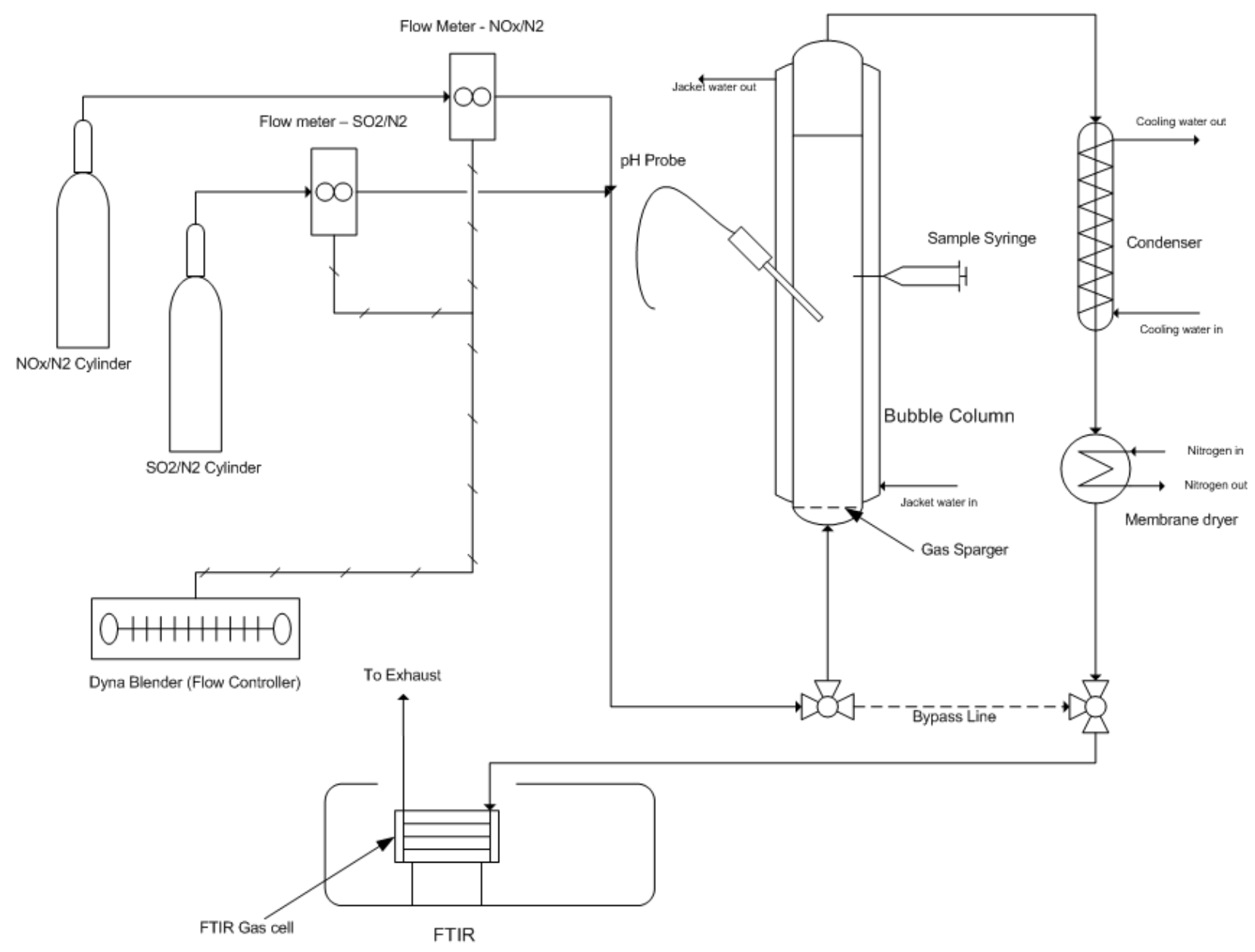

Figure 1. 

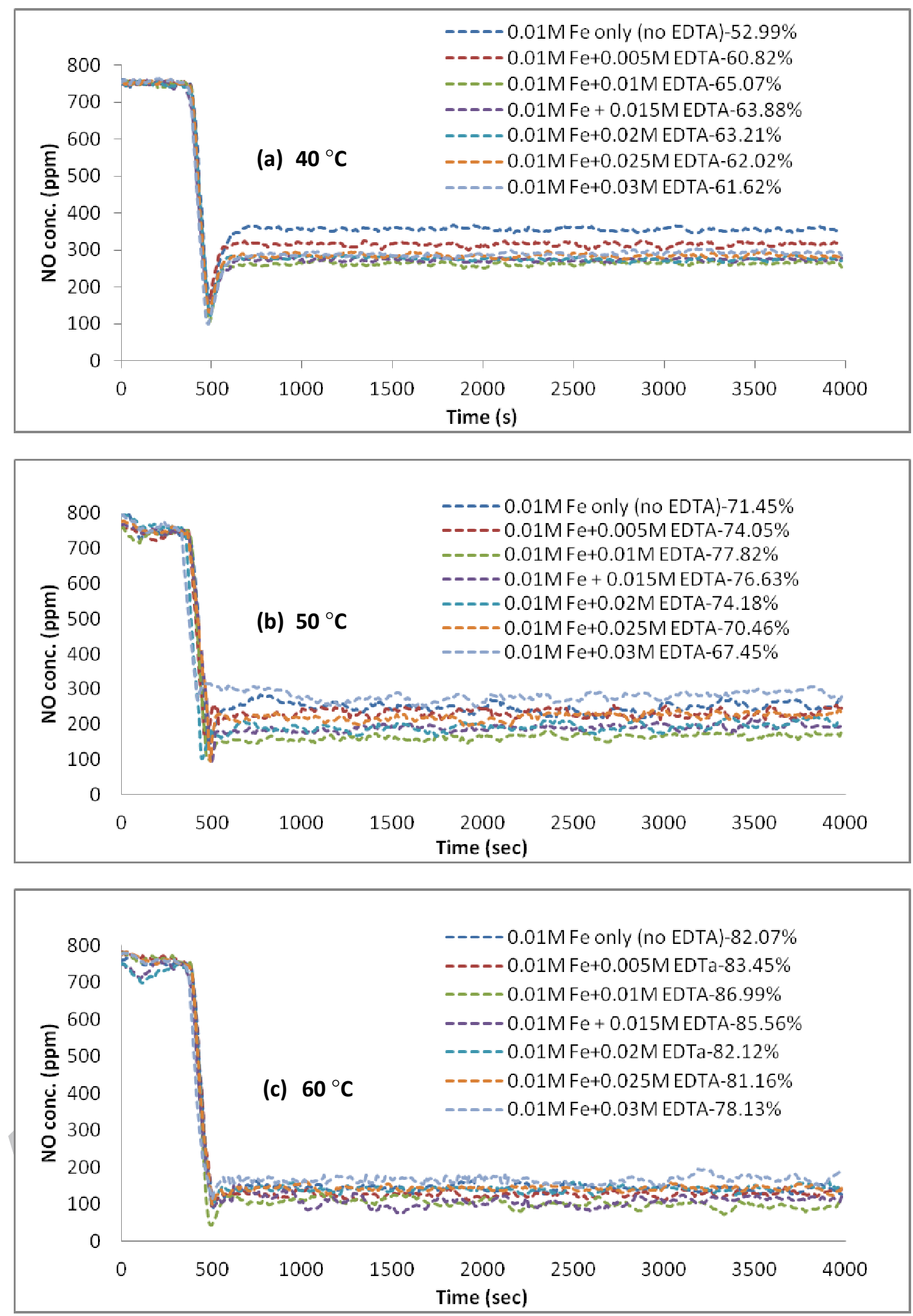

Figure 2 


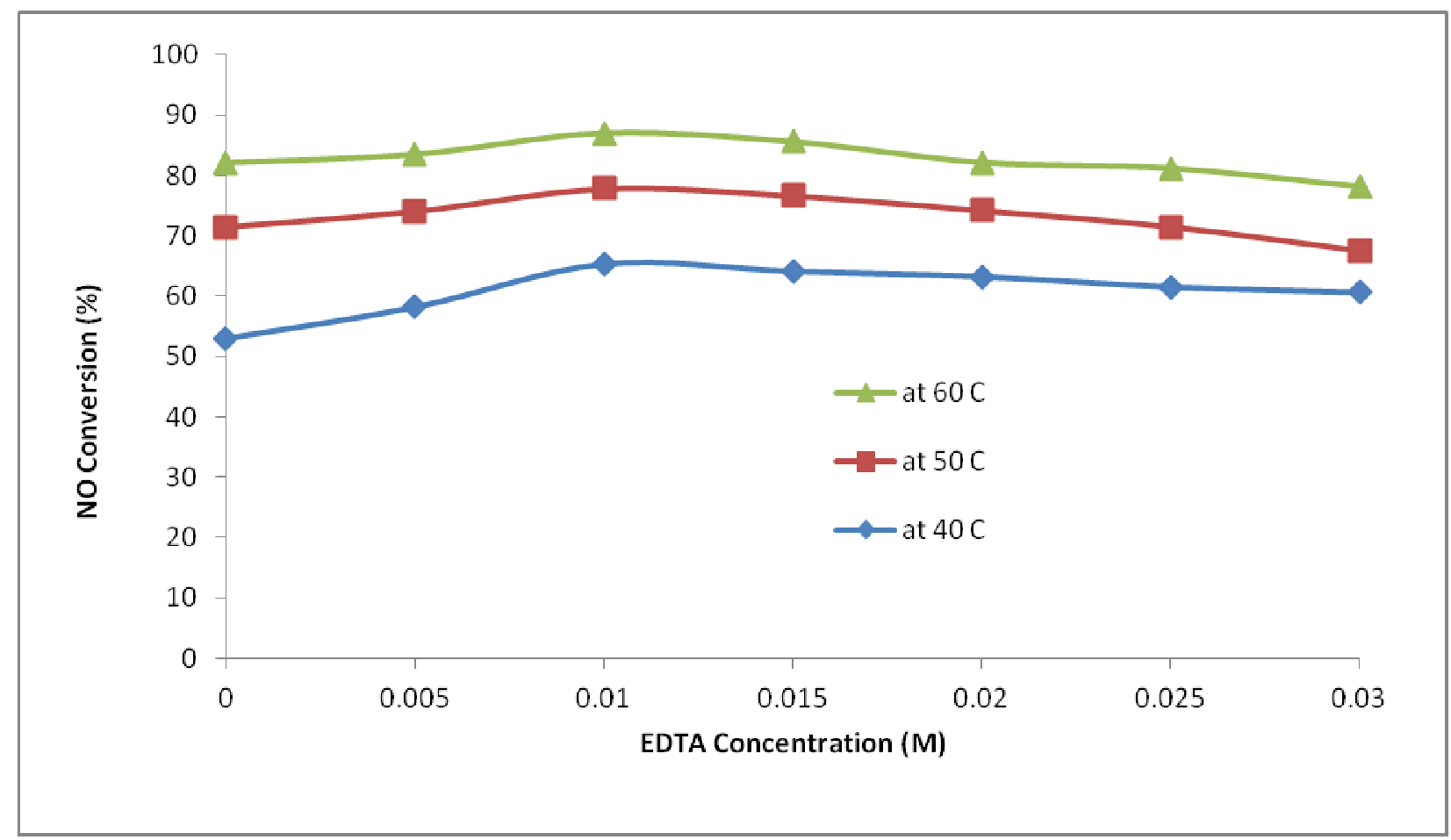

Figure 3

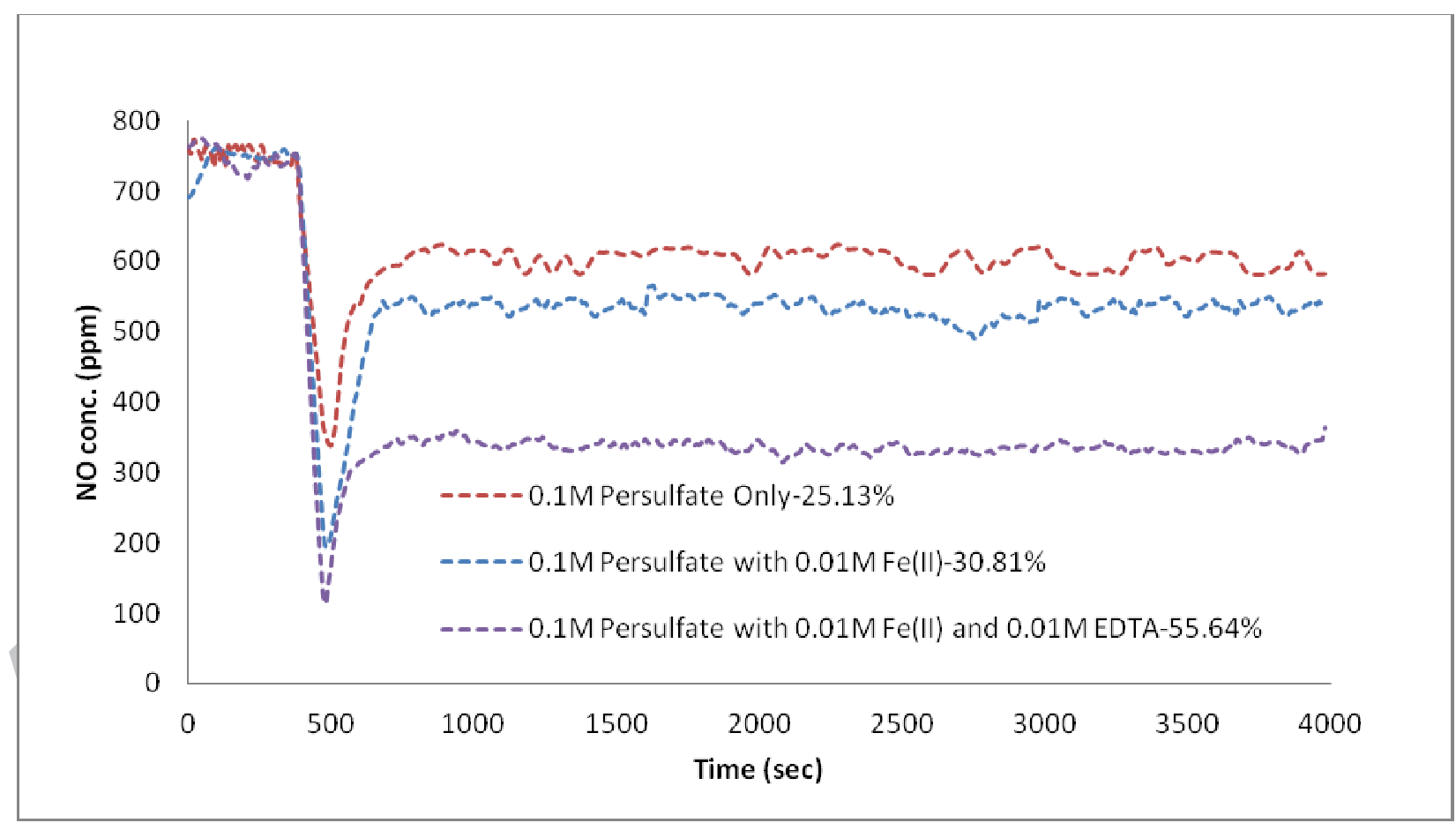

Figure 4 

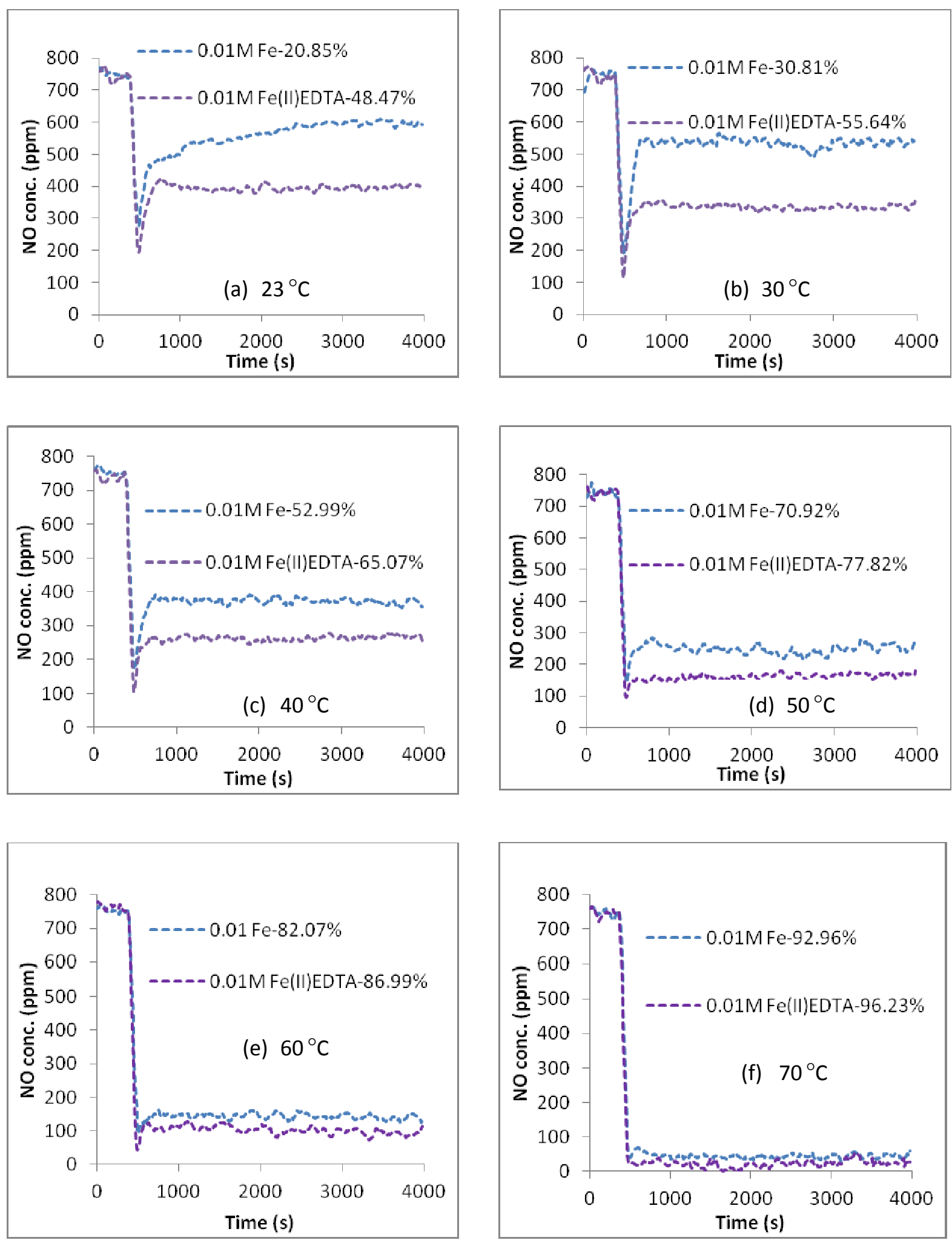

Figure 5 


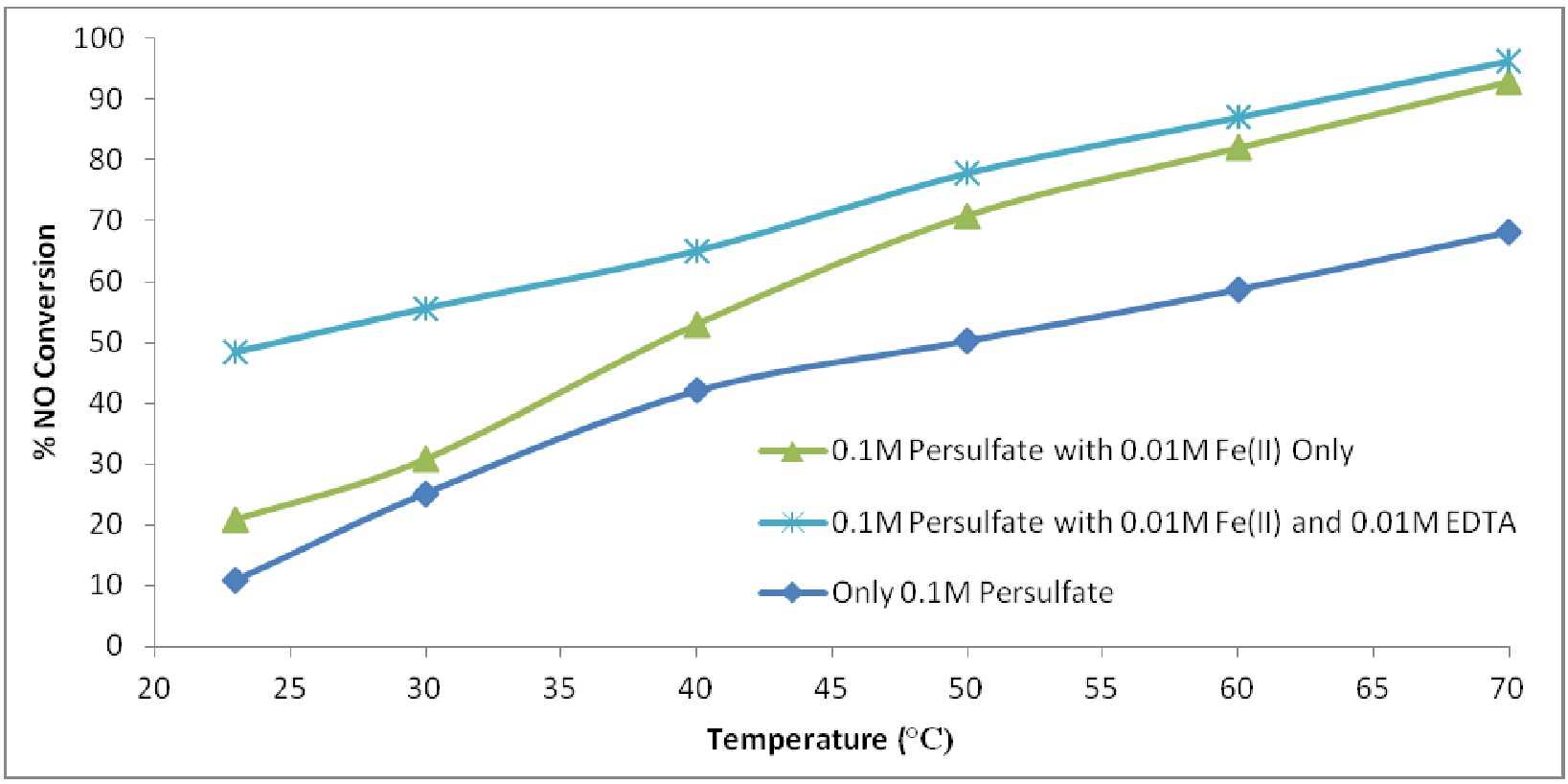

Figure 6

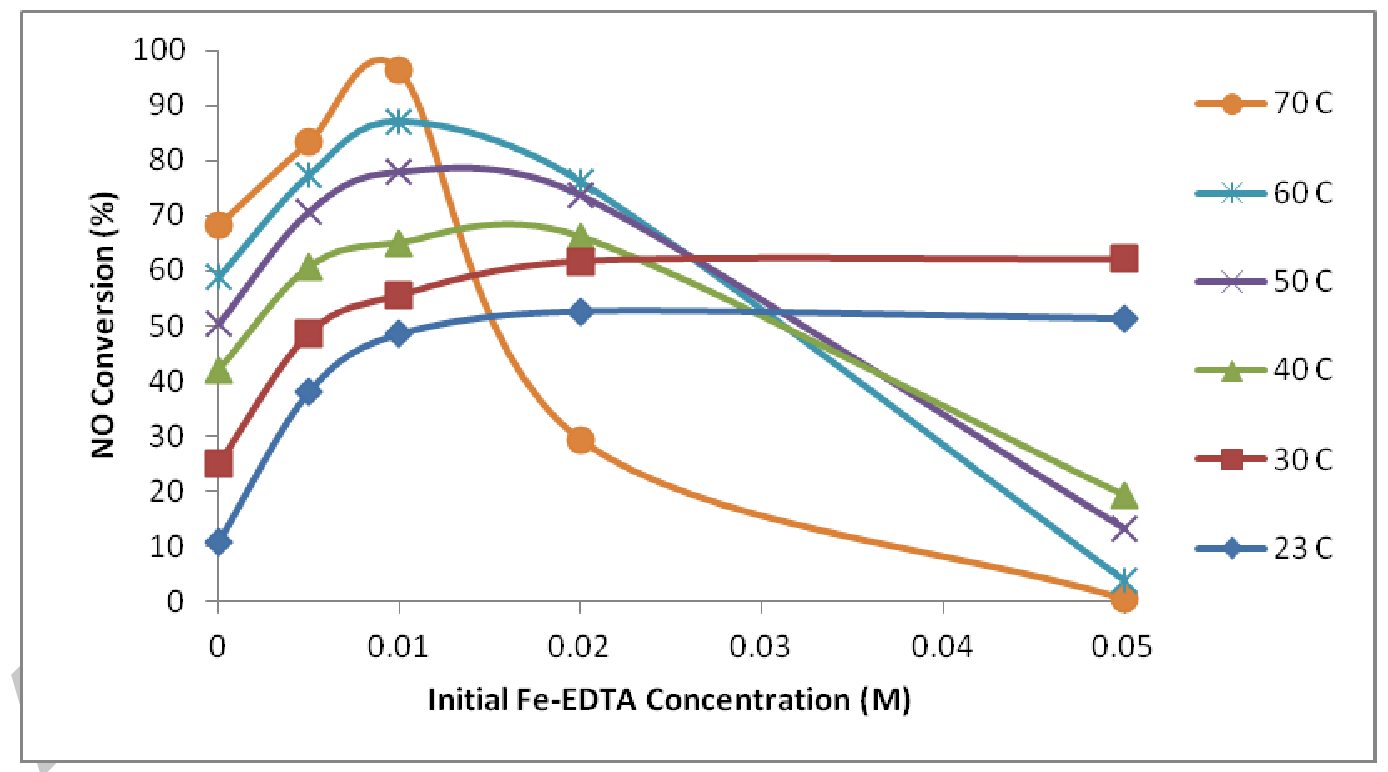

Figure 7 


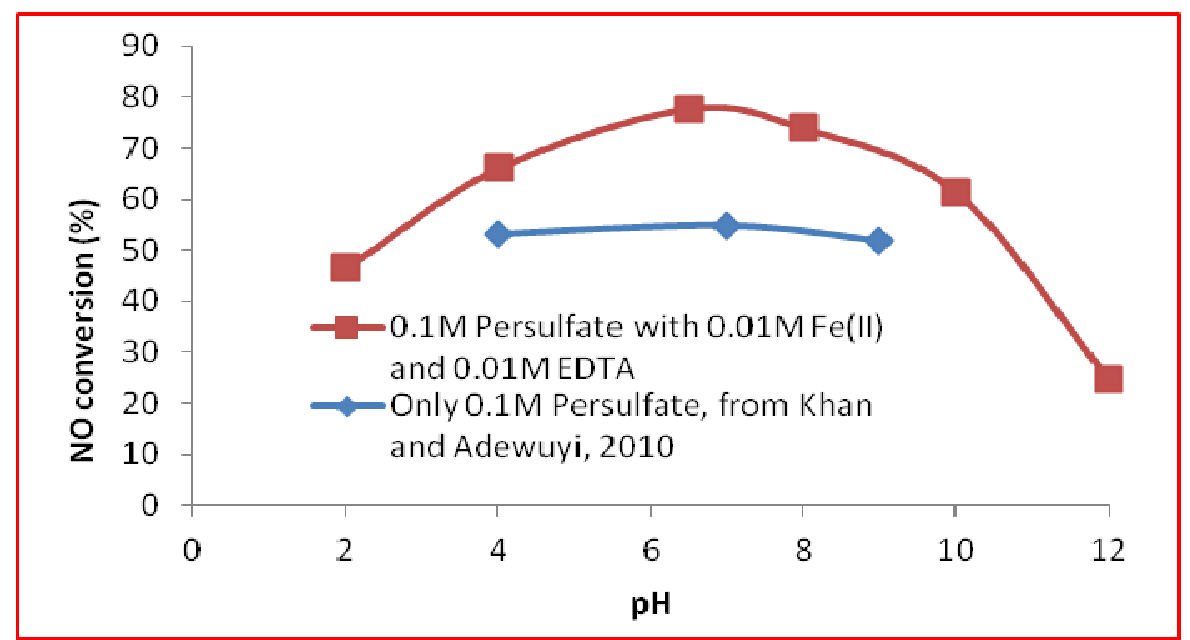

Figure 8 

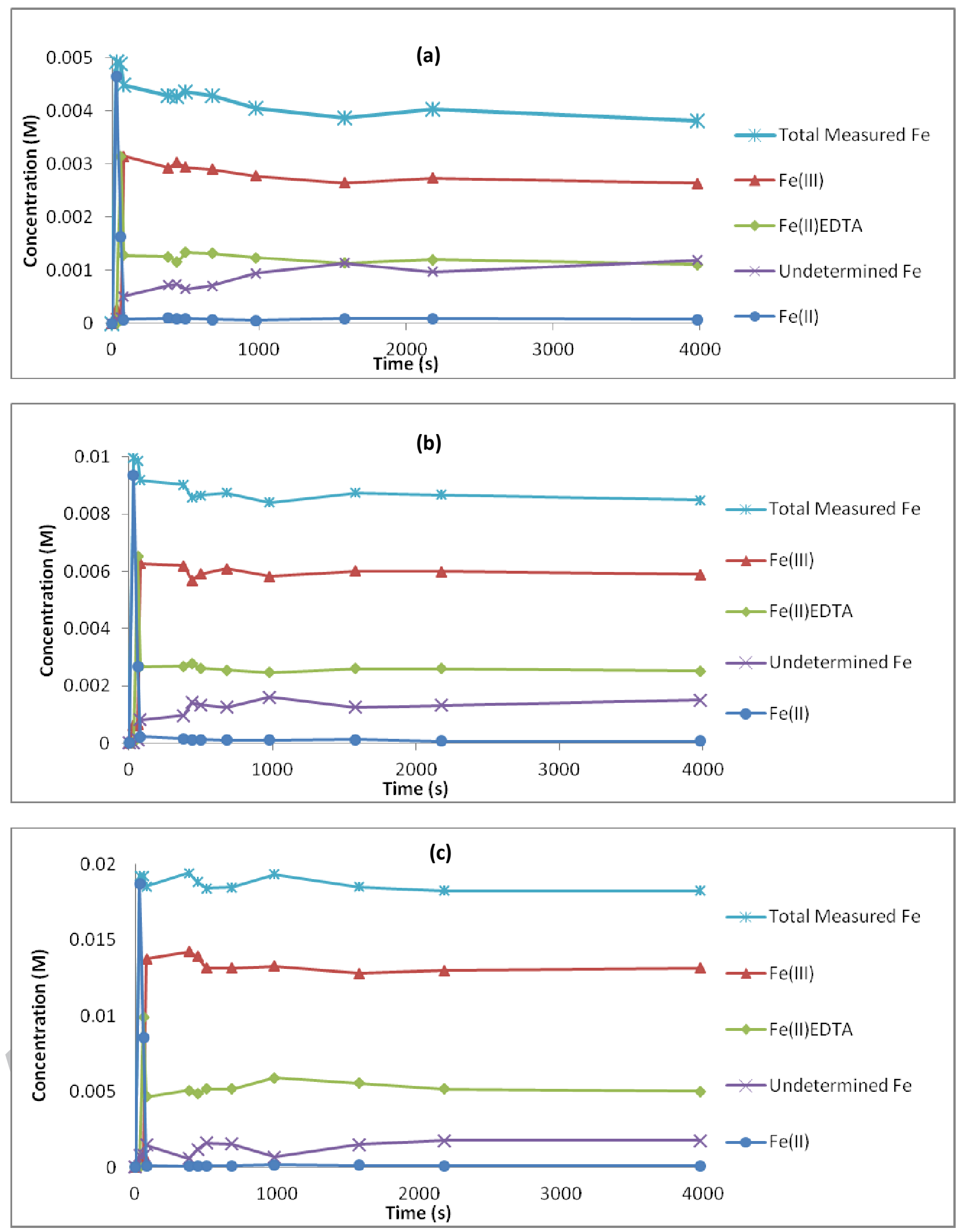

Figure 9 

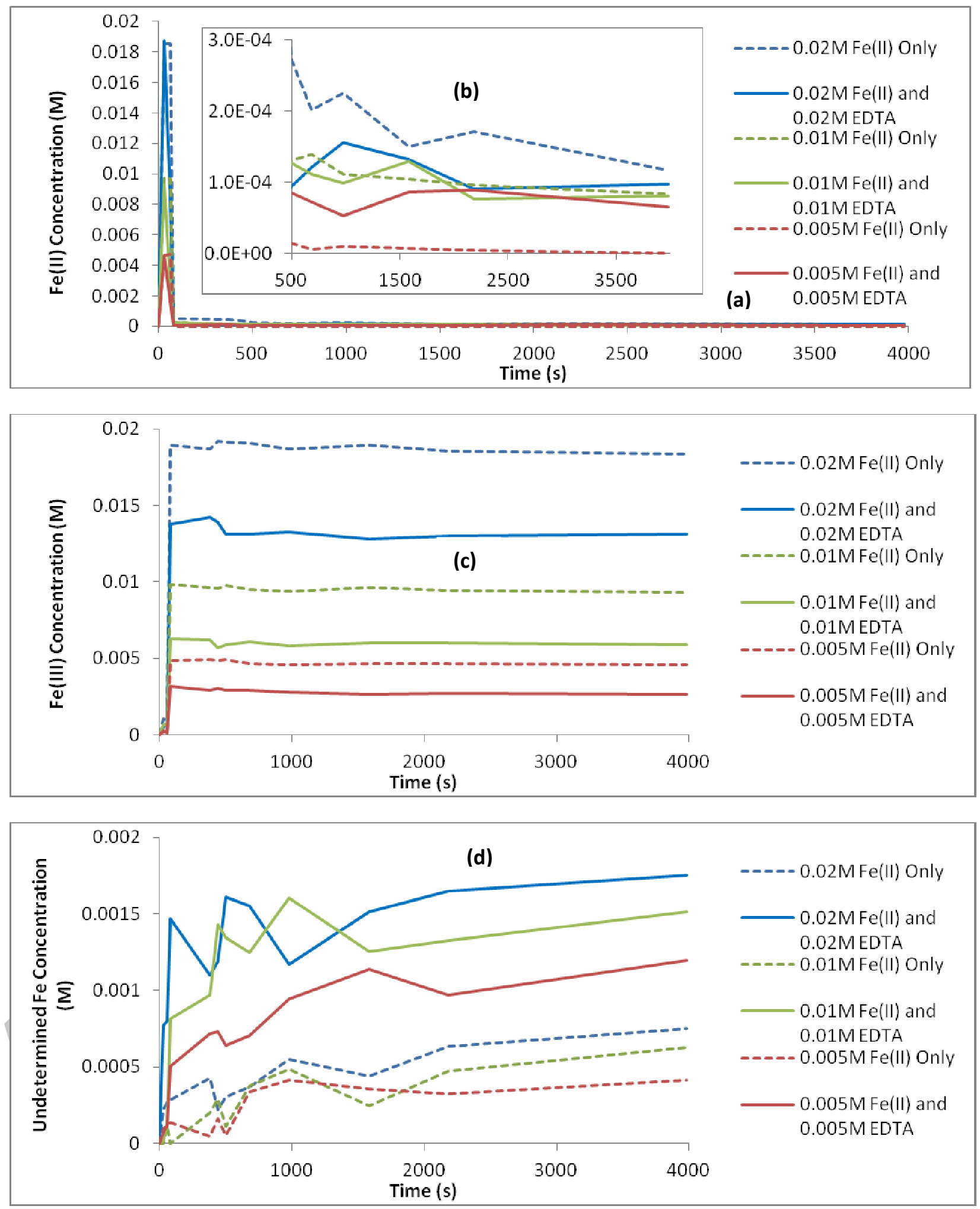

Figure 10 